\title{
THE STYLE, TECHNOLOGY AND ORGANIZATION OF SICÁN MINING AND METALLURGY, NORTHERN PERU: INSIGHTS FROM HOLISTIC STUDY*
}

\author{
EL ESTILO, TECNOLOGÍA Y ORGANIZACIÓN DE LA MINERÍA Y METALURGIA \\ SICÁN, NORTE DEL PERÚ: VISIONES DESDE UN ESTUDIO HOLÍSTICO
}

\author{
Izumi Shimada ${ }^{1}$ and Alan K. Craig ${ }^{2}$
}

\begin{abstract}
This paper explains what Shimada has termed a holistic approach to craft production and illustrates its value by discussing insights gained into the style, technology, and organization of Middle and Late Sicán (ca. AD 900-1,375) mining and copper-arsenic metallurgy. After a brief characterization of the geographical and cultural settings of pertinent research by the Sicán Archaeological Project (1978-present) and the holistic approach, we discuss specific methods and strategies for locating and dating pre-Hispanic mines. Based on our examination of eight mines in the study area that supplied copper oxides and/or arsenic-bearing ores, we offer a general characterization of Sicán mining, emphasizing the integral character of local mining and autochthonous copper-arsenic alloy (also called arsenical bronze) production at nearby smelting sites (six excavated to date). Our analyses of primary context samples of ore and smelting products and by-products recovered at smelting sites show that copper-arsenic was deliberately and locally smelted and that arsenic was derived from scorodite (oxide form of arsenopyrite) and/or weathered sulfide ores available near the surface of local mines. Additionally, we discuss insights gained into careful and sustainable charcoal fuel management and the "modular organization" of metallurgical and other productive activities.
\end{abstract}

Key words: Sicán, holistic approach, copper-arsenic, Andean archaeometallurgy.

Este documento explica lo que Shimada ha denominado enfoque holístico del estudio de la producción artesanal antigua y ejemplifica su valor discutiendo perspicacias adquiridas acerca del estilo, tecnología y organización de la minería y metalurgia Sicán Medio y Tardío (ca. 900-1.375 d.C.). Luego de una caracterización de los marcos geográfico y cultural del Proyecto Arqueológico Sicán (1978-presente) y del enfoque holístico, discutimos métodos y estrategias específicas para ubicar y datar las minas prehispánicas. Basados en nuestra evaluación de ocho minas en el área de estudio que proveían de óxidos de cobre y/o minerales conteniendo arsénico, ofrecemos una caracterización general de la minería Sicán, enfatizando el carácter integral de la minería local y producción autóctona de cobre arsenical en sitios cercanos de fundición. Nuestros análisis de muestras de minerales y productos y subproductos de fundición muestran cómo las aleaciones de cobre arsenical fueron deliberadas y fundidas localmente, y que el arsénico fue derivado de la escorodita (óxido de arsenopirita) y/o minerales sulfuros erosionados disponible cerca la superficie de las minas locales. Adicionalmente, discutimos visiones adquiridas acerca del manejo cuidadoso y sostenible del combustible de carbón vegetal y de la "organización modular" de la metalurgia y otras actividades productivas.

Palabras claves: Sicán, enfoque holístico, cobre arsenical, arqueometalurgia andina.

Over 100 years of scientific investigation into indigenous New World metallurgy that began in the late $19^{\text {th }}$ century (e.g., Bergsøe 1937, 1938; Boman 1908; Cushing 1894; Mathewson 1915; Mead 1915; Nordenskiöld 1921) have revealed that Peru and neighboring countries distinguished themselves in terms of technological developments as well as by the quantity, diversity and cultural significance of metal products. In fact, as early as 1921, Erland Nordenskiöld (1921) recognized the cultural importance and distinct character of north coast metallurgy. Over the next decades, technical and artistic studies documented the remarkable sophistication, innovative character and versatility of what was essentially a copper and copper-alloy based metallurgy (e.g., Caley 1973; Caley and Shank 1971; Jones 1979; Lechtman 1973, 1984, 1988; Lechtman et al. 1982; Patterson 1971; Shimada 1994a, 1999).

While important advances were made in north coast archaeometallurgy, the resultant vision was rather truncated and perhaps even distorted by the predominant focus on finished objects looted from elite funerary contexts that

\footnotetext{
* Artículo seleccionado del conjunto de ponencias presentadas en la Primera Reunión Internacional sobre Minería Prehispánica en América (PRIMPA), realizada en San Pedro de Atacama, Chile, diciembre 2010. Este manuscrito fue evaluado por investigadores externos y editado por Diego Salazar y Valentina Figueroa, en su calidad de editores invitados de la Revista.

1 Department of Anthropology, Southern Illinois University, 1000 Faner Drive, Carbondale, IL 62901 U.S.A. ishimada@ siu.edu

22556 Sundy Ave, Delray Beach, FL 33444-2130 mary2861@ gmail.com
} 
lacked crucial contextual information and overrepresented the final segment of what was, in reality, a long, multi-phase production process. While Lechtman's (1976) macro-scale survey of ancient mines and metallurgical sites provided a valuable pan-Peruvian overview and effectively complemented the earlier, pioneering works of A. Raimondi (1878, 2004[1889]; also Villacorta 2004) and G. Petersen (1970), efforts to locate and excavate mines and associated smelting and smithing workshops on the north coast (and for much of the Andes) subsequently have been relatively rare and/or of short in duration (e.g., Bernier 2010; Oehm 1984; Topic 1990).

Understandably, the paucity of in-depth studies of primary production and use contexts has hampered discussion of issues such as the organization and social relations of production (e.g., Costin and Wright 1998) and unbiased assessment of the distribution, use and value of products across the entire social spectrum. Metallurgy is, indeed, much more than a technology for transforming metallic ores to usable metals; technical and artistic studies, and surveys alone cannot effectively elucidate the complex set of behavioral, material, social and ideological variables and processes that interact with and shape it. Thus, we needed to strive for a comprehensive understanding of the many components, phases, and functions as well as significance of metallurgy and its products within appropriate social and historical contexts (emphasis added) This ambitious aim called for long-term, focused, interdisciplinary investigation of integrated mining and metallurgical complexes and (b) their broader regional contexts (emphasis added).

The interconnected complex of the Cerro Blanco mine and the nearby Cerro Huaringa-Cerro Sajino metallurgical complex (hereafter identified as the Co. H-S Complex; Shimada et al. 1982; Shimada and Merkel 1987; Figures 1,2,3) that Shimada first surveyed in 1978 offered a rare and ideal research setting for just such a purpose. The complex is situated just south of the town of Batán Grande in the mid-La Leche Valley on the north coast of Peru. Since then, our effort to maximize the potential of this research setting and to achieve what Shimada (see below) has called a holistic understanding of Sicán craft production has been the driving force behind over three decades of research by the Sicán Archaeological Project.
This paper has two aims: to explicate our holistic approach to craft production in general and, more specifically, to illustrate its value by discussing some of the insights we have gained into the style, technology and organization of the Sicán mining and metallurgy. After a brief characterization of the geographical and cultural settings of pertinent research by the Sicán Archaeological Project and the holistic approach, we discuss specific methods and strategies for locating and dating pre-Hispanic mines. Based on our examination of pre-Hispanic mines in the study area that supplied copper oxides and/or arsenic-bearing ores, we offer a general characterization of Sicán mining and metallurgy, emphasizing the integral character of local mining and autochthonous copper-arsenic production at nearby smelting sites. Additionally, we discuss insights gained into careful and sustainable charcoal fuel management and the "modular organization" of metallurgical and other productive activities.

\section{Holistic Approach}

The holistic approach to craft production is built on a broadly inclusive conception of productive activities and aims to (1) define and explicate the technology and organization of the entire production process from acquisition of necessary ingredients and product preparation to recycling of products and byproducts, and (2) understand the functions, significance and distribution of products, as well as the social conventions and institutions, social relations of workers, and value system that influenced the manufacture, use and meaning of products (Shimada 1985a, 1994a; Shimada et al. 1994, 1999; Shimada and Merkel 1987; Shimada and Wagner 2007). It is holistic in the sense of embracing diachronic and synchronic as well as material and human dimensions of productive activities. Figure 4 illustrates key components of this approach and how they interrelate.

Our general conception of craft production resembles those of the châine opératoire (e.g., Dobres and Hoffman 1994; Lemonnier 1993; Sellet 1993; Sillar and Tite 2000), object biography (Gosden and Marshall 1999; Jones 2002), and others that different scholars (e.g., Costin 2001; Lechtman 1977; Schiffer and Skibo 1987) have advocated independently. Our holistic approach, however, distinguishes itself in prioritizing focused studies of production sites and the diverse use contexts of their products by 


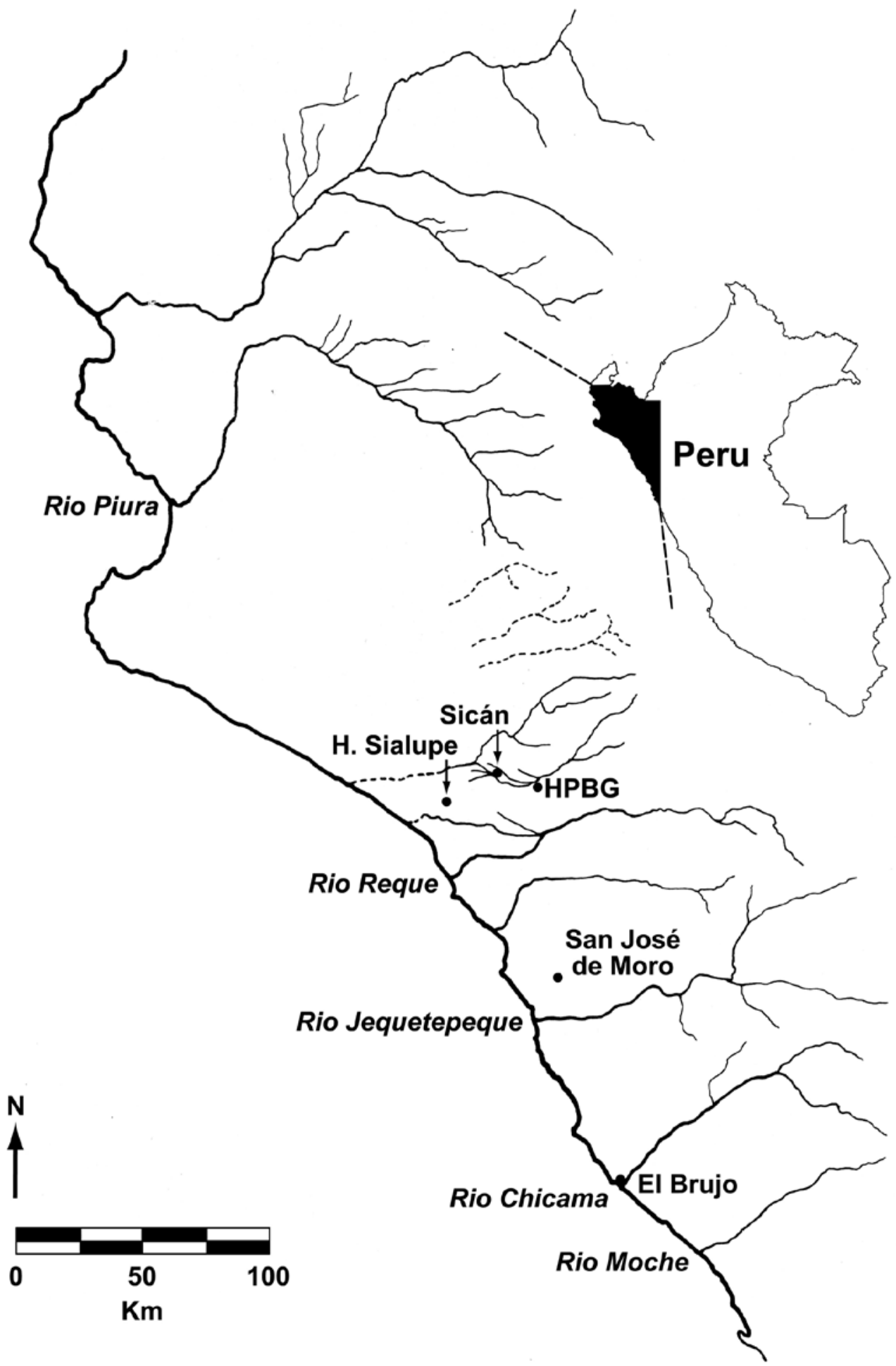

Figure 1. Northern north coast with major modern settlements and archaeological sites. HPBG refers to Huaca del Pueblo Batán Grande. Prepared by Izumi Shimada.

Mapa de la parte norte de la costa norte del Perú señalando ríos principales y sitios arqueológicos pertinentes al presente estudio. Se refiere HPBG al sitio de Huaca del Pueblo Batán Grande. Elaborada por Izumi Shimada. 


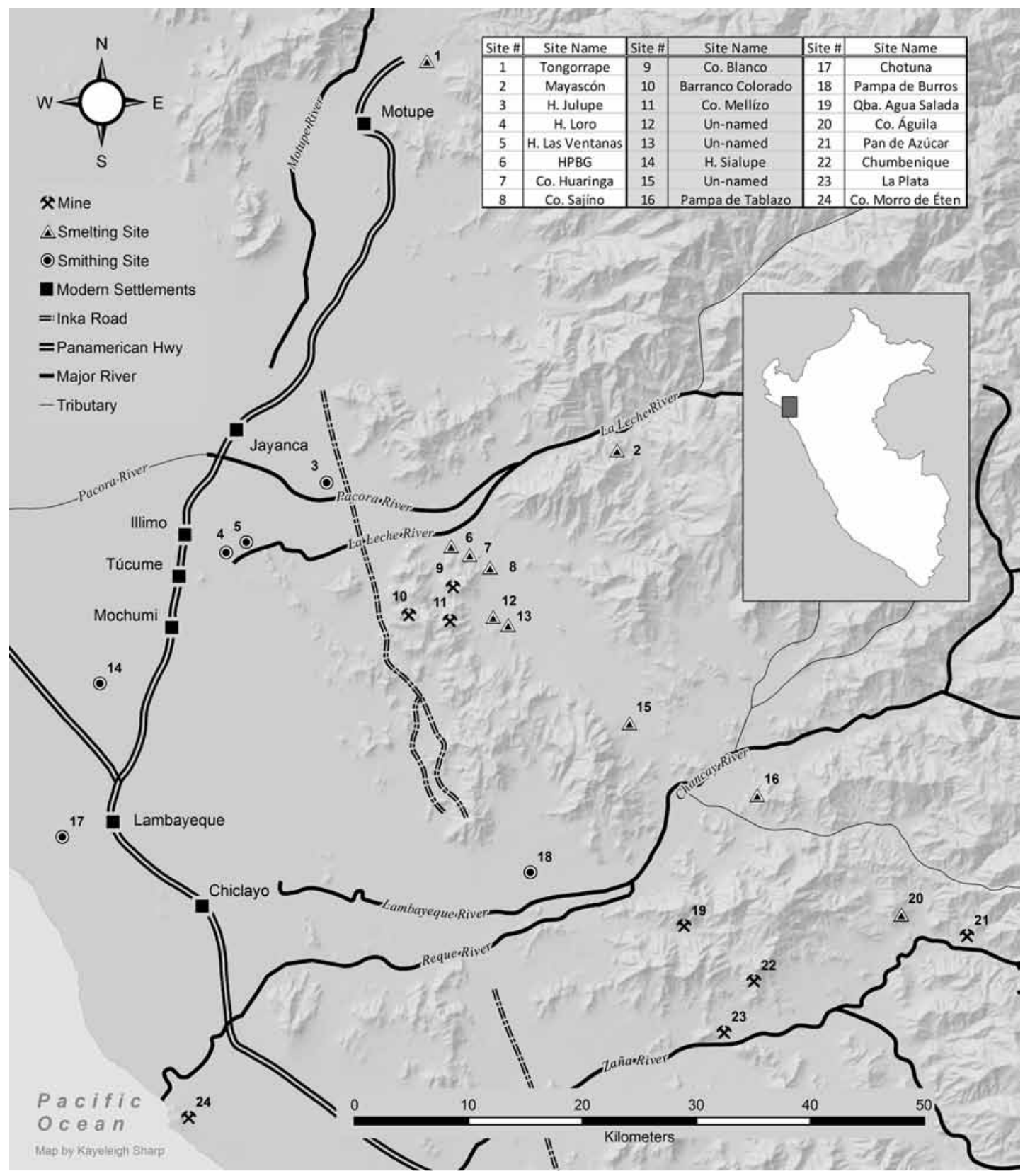

Figure 2. The study area with locations of mines, smelting and metalworking sites, and associated roads. Prepared by Kayeleigh Sharp. La zona de nuestro estudio señalando las ubicaciones de minas, sitios de fundición y metalistería y caminos asociados. Elaborada por Kayeleigh Sharp.

means of long-term interdisciplinary collaboration both in and out of the field (emphasis added). The pursuit of production sites and diverse use contexts as well as identification of production ingredients and workers requires regional multi-site sampling and survey (emphasis added). Analysis and interpretation of the evidence thus obtained are based on the four complementary methods of archaeometry, experimental archaeology (both laboratory and field), ethnoarchaeology, and the comparative study of existing artifact collections (Figure 4). These methods form a critical, self-directed, self-corrective process. Samples and/or insights gained from one method are independently verified through one or 


\section{Batán Grande Mining-Metallurgical Complex}

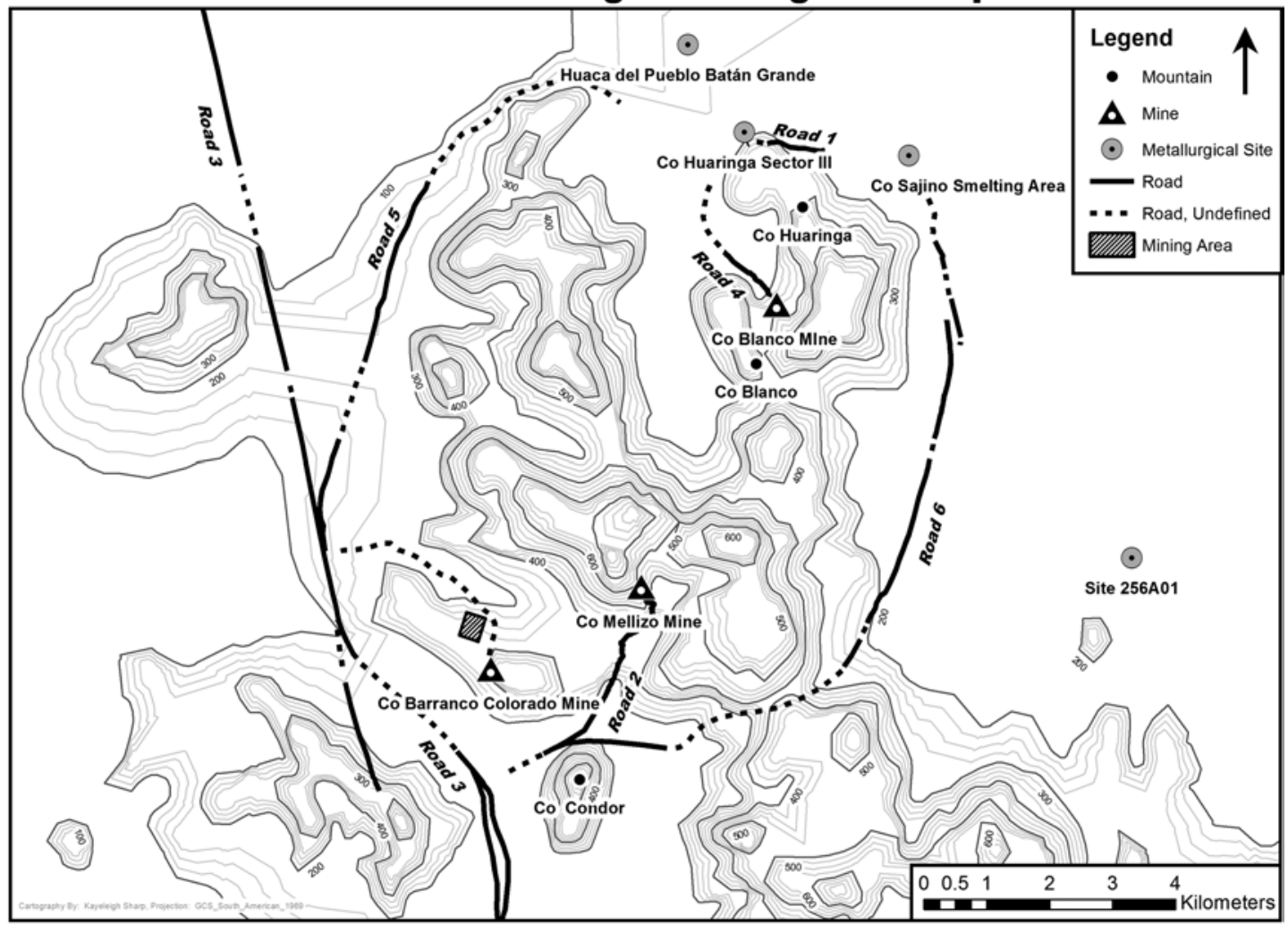

Figure 3. The integrated Batán Grande Metallurgical Complex and its constituent mines of Cerro Blanco, Cerro Mellizo, and Barranco Colorado, and Sicán smelting sites interconnected by roads. Prepared by Kayeleigh Sharp.

El Complejo Metalúrgico Integrado de Batán Grande y sus minas componentes en Cerro Blanco, Cerro Mellizo y Barranco Colorado y sitios de fundición Sicán interconectado por caminos. Elaborada por Kayeleigh Sharp.

more other remaining methods. Highly controlled and replicable laboratory experiments and more realistic but harder to control field experiments are also reciprocally informative (Shimada 2005; Shimada et al. 2003; Skibo 1992).

\section{Sicán Culture and the Study Area}

\section{Study Area}

The Sicán was a prominent pre-Hispanic culture that emerged in the $9^{\text {th }}$ century centered in the Lambayeque Complex on the northern north coast of Peru (corresponding to our study area; Figure 2) and persisted until the end of the $14^{\text {th }}$ century (Table 1 ). The Complex consisted of the four contiguous (north to south) Motupe, La Leche, Lambayeque, and Zaña river valleys that were hydrologically interlinked by four major intervalley canals (Jayanca, Racarumi, Taymi and Collique). At the height of the
Sicán culture some 1,000 years ago, Kosok (1959, 1965) estimated that the Complex encompassed a third of the total cultivated land on the Peruvian coast, while Schaedel (1972) calculated its resident population size to have been 1.0 to 1.5 million. Extensive metallic ore deposits in the foothills of the constituent valleys and productive year-round, intensive fishing effectively complemented largescale irrigation agriculture to provide the Sicán with

Table 1. Sicán chronology. Cronología de Sicán.

\begin{tabular}{cc}
\hline Sicán Inca & AD $1,460 / 70-1,532$ \\
\hline Sicán-Chimú & AD $1,375-1,460 / 70$ \\
Late Sicán & AD $1,100-1,375$ \\
Middle Sicán & AD $900-1,100$ \\
Early Sicán & AD 750/800 - 900 \\
\hline
\end{tabular}




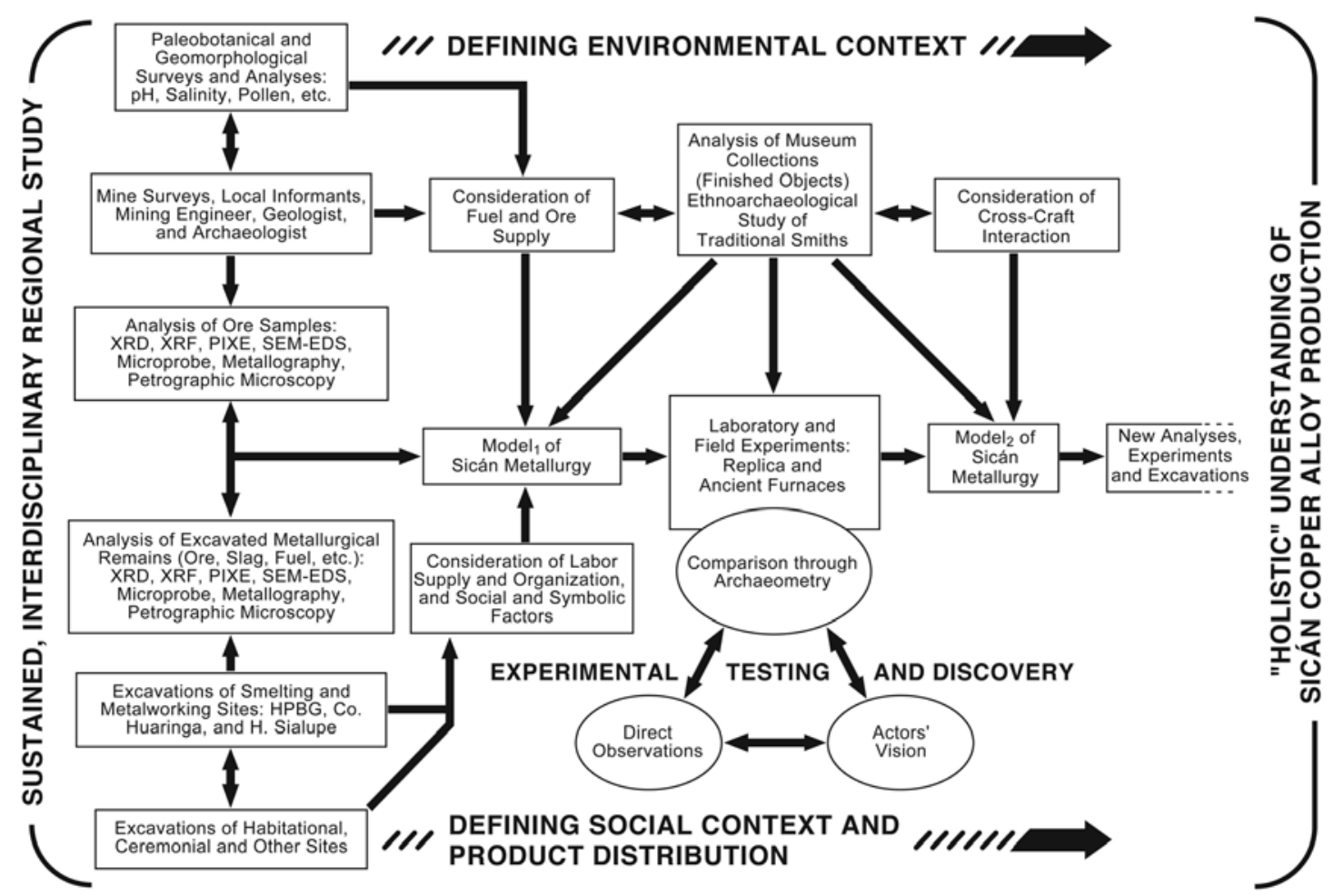

Figure 4. Graphic representation of the components of the holistic approach and their interrelationship. Prepared by Izumi Shimada and Steven Muller.

Representación gráfica de los componentes del Enfoque Holístico y su interrelación. Elaborada por Izumi Shimada y Steven Muller.

what was probably the most productive economic foundation and greatest demographic potential of the entire coast for their time period.

\section{Sicán Culture}

The Sicán culture began forging its distinctive character (corresponding to the Early Sicán period) by fusing selected autochthonous features of the persistent, local Moche (also known as Mochica) cultural tradition with exogenous features related to relatively transient Wari and Pachacamac influence from the south. The nature of their interaction and subsequent developmental processes are still not well understood (Castillo 2001; Chapdelaine 2010; Mackey 2000; Menzel 1977; Schaedel 1993; Shimada 1985b, 1990). This cultural hybridization, together with the waning of the Wari Empire around AD 900 and the aforementioned impressive productive capacity of the Lambayeque Complex, formed the basis for the rapid formalization of the Sicán religion and associated art style as well as its notable economic growth and political power.
During this florescent Middle Sicán period, AD 900-1,100, the Sicán established a state-level polity, a stratified, multi-ethnic society, ideological and political dominance over at least $350 \mathrm{~km}$-stretch of the northern north coast (at least spanning from the Chira Valley to the north to the Chicama Valley to the south) and a far more extensive interaction sphere that included a trade network that reached Colombia to the north and the south-central Peru to the south (Segura and Shimada 2012; Shimada 2000, 2009).

Among the most distinguishing and important legacies of the Middle Sicán culture were innovative and advanced pyrotechnologies. Their metallurgists distinguished themselves in successfully producing copper-arsenic alloys and gold alloys on an unprecedented scale and employing them for a wider range of use than ever before (e.g., Shimada 1994a; Shimada et al. 1999, 2000; Shimada and Griffin 1994; Shimada and Merkel 1991). Documented Middle Sicán elite tombs often contain many precious metal objects as well as hundreds, if not thousands, of both sheet and solid cast copper-arsenic alloy 


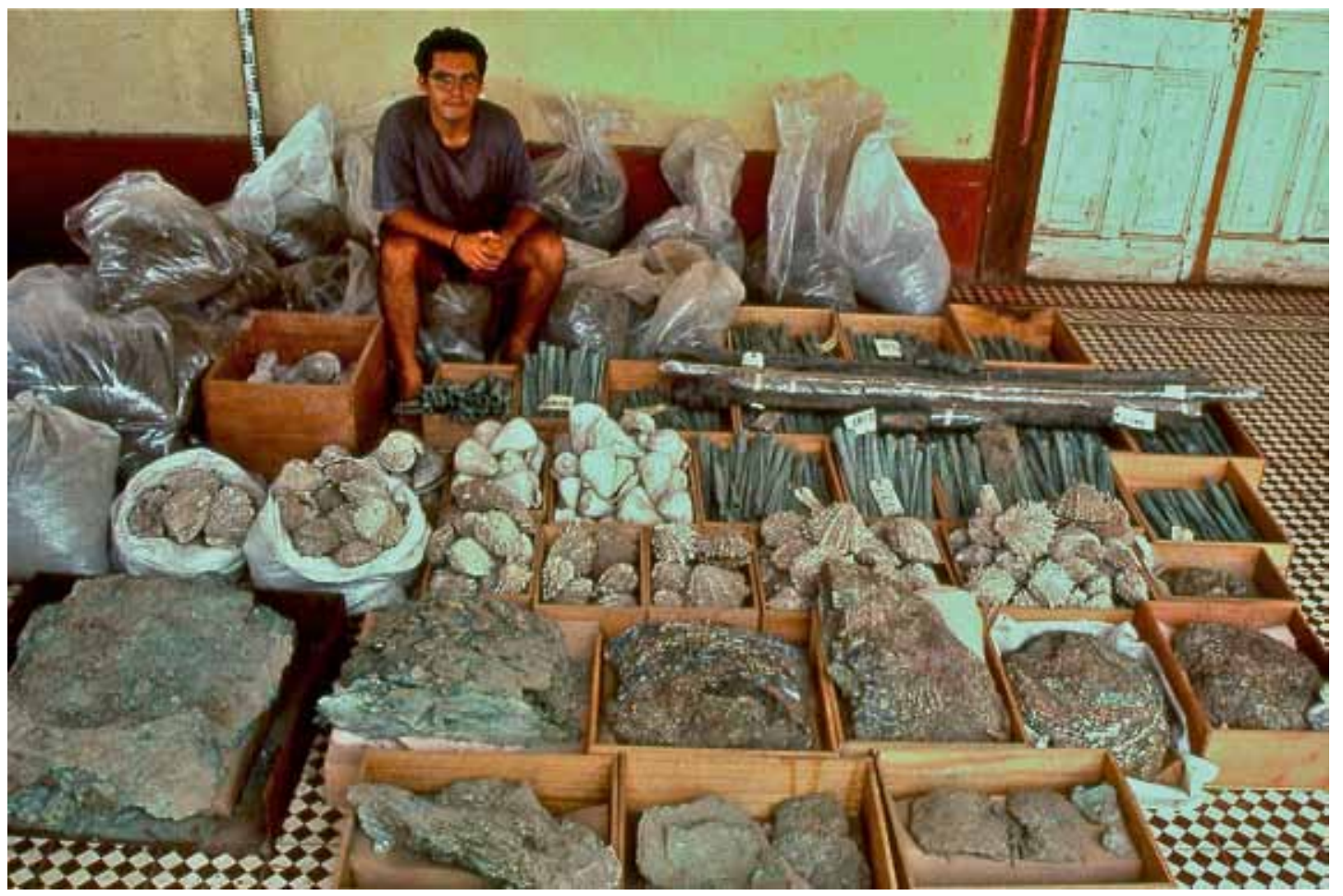

Figure 5. Approximately 1.2 tons of grave goods recovered from the Huaca Loro East Tomb. Most of the weight and the objects seen in the foreground are copper-arsenic products. Photo by Izumi Shimada.

El ajuar funerario de la Tumba Este de Huaca Loro que en total pesa aproximadamente 1,2 toneladas. La mayoría del peso y los objetos visibles en primer plano son productos de cobre-arsénico. Foto de Izumi Shimada.

objects totaling hundreds of kilograms in weight (Pedersen 1976; Shimada 1995; Shimada et al. 2000). Among the diverse grave goods found in the East Tomb ( $3 \times 3 \mathrm{~m}$ and $11 \mathrm{~m}$ deep) at the north base of the monumental temple mound of Huaca Loro, Sicán, were over 60 major high-karat gold alloy ornaments and 489 cast copper-arsenic alloy agricultural tools (in 15 tied bundles) weighing a total of nearly $200 \mathrm{~kg}$ (Figure 5).

Copper-arsenic alloys replaced pure copper as the utilitarian metal of northern Peru until the Spanish conquest (Cleland and Shimada 1992; Shimada and Merkel 1991). Metals permeated all facets of this culture and differentiated access to different metals served as a visible marker of social status (Shimada 1994b). At the same time, their potters succeeded in large-scale production of well-fired, true blackware, often with a metallic sheen (Shimada and Wagner 2001) and forms that clearly emulated more prestigious metallic vessels (Cleland and Shimada 1992; Rondón 1965/66). The pottery became widely valued, engendering an unparalleled popularity of black ceramics that rapidly spread along much of the Peruvian coast and persisted until Spanish conquest.

Perhaps in response to impacts of an El NiñoENSO event (ca. AD 1,050) of historic proportions that compounded the adverse effects of an immediately preceding severe drought (ca. AD 1,020-1,050; Craig and Shimada 1986; Shimada et al. 1991), Sicán society underwent an unprecedented reorganization (Jennings 2008; Shimada 2000, 2009). Late Sicán culture (AD 1,100-1,375) featured a new capital at Túcume at the juncture of the La Leche and the Lambayeque valleys, abandonment of the Sicán Deity veneration, and truncation of the trade network. Copper-alloy production, however, continued during this period (Epstein and Shimada 1984).

Around AD 1,375, the expanding Chimú Empire intruding from the south conquered the Late Sicán polity, ending its political autonomy (Shimada 1990, 2000). The Chimú and the Inca, who conquered the Chimú ca. AD 1,460-70, both recognized the superiority and importance of Sicán metallurgy and intensified its production relocating many workers to their respective capitals of Chan Chan and 
Cusco (Shimada 2000, 2009; Topic 1990). Thus, Sicán metallurgy lived on long after the demise of the Sicán polity.

\section{Applying the Holistic Approach to Sicán Mining and Metallurgy}

\section{Locating Pre-Hispanic Mines}

We employed various methods to locate preHispanic mines in our study area with a particular emphasis on the area just south of the modern town of Batán Grande where the Co.H-S Complex is situated. We began with examination of a regional geological map prepared by the Instituto Geográfico Militar del Perú and different sets of conventional vertical, black-and-white airphotos acquired from the Servicio Aerofotográfico Nacional del Perú, and, later, remote sensing images taken by the Landsat, Space Shuttle, and Earth Observing System [EOS]. Remote sensing images proved to be unproductive because of problems of scale and inadequate visual resolution. Many pre-Hispanic workings are too small to be detected in images at the scale available today. The same scale problem hampers the use of conventional airphotos. Theoretically, very large scale photos (i.e., $\leq 5,000$ ) could be specially obtained to overcome this problem, assuming local relief did not cause too much vertical distortion, but it would be quite costly for prospecting large areas.

Airphotos $(1: 10,000)$ were useful in identifying local mineralization sources such as dome-shaped Cretaceous igneous intrusions like Cerro Blanco and Cerro Condor (Figure 6) south of the town of Batán Grande. They may appear as "extrusions" due to exposure by post-Cretaceous erosion. Just as the Cerro Blanco mine is situated in a mineralized zone just east of the light-colored, massive intrusion, we suspected that there would be mines in the area surrounding Cerro Condor. As remote sensing by whatever means always requires a thorough ground check to confirm the interpretations that have been made, we tested our prediction by targeting this area for intensive pedestrian surveys assisted by local inhabitants and a prospector/mining engineer, Luis Suarez.

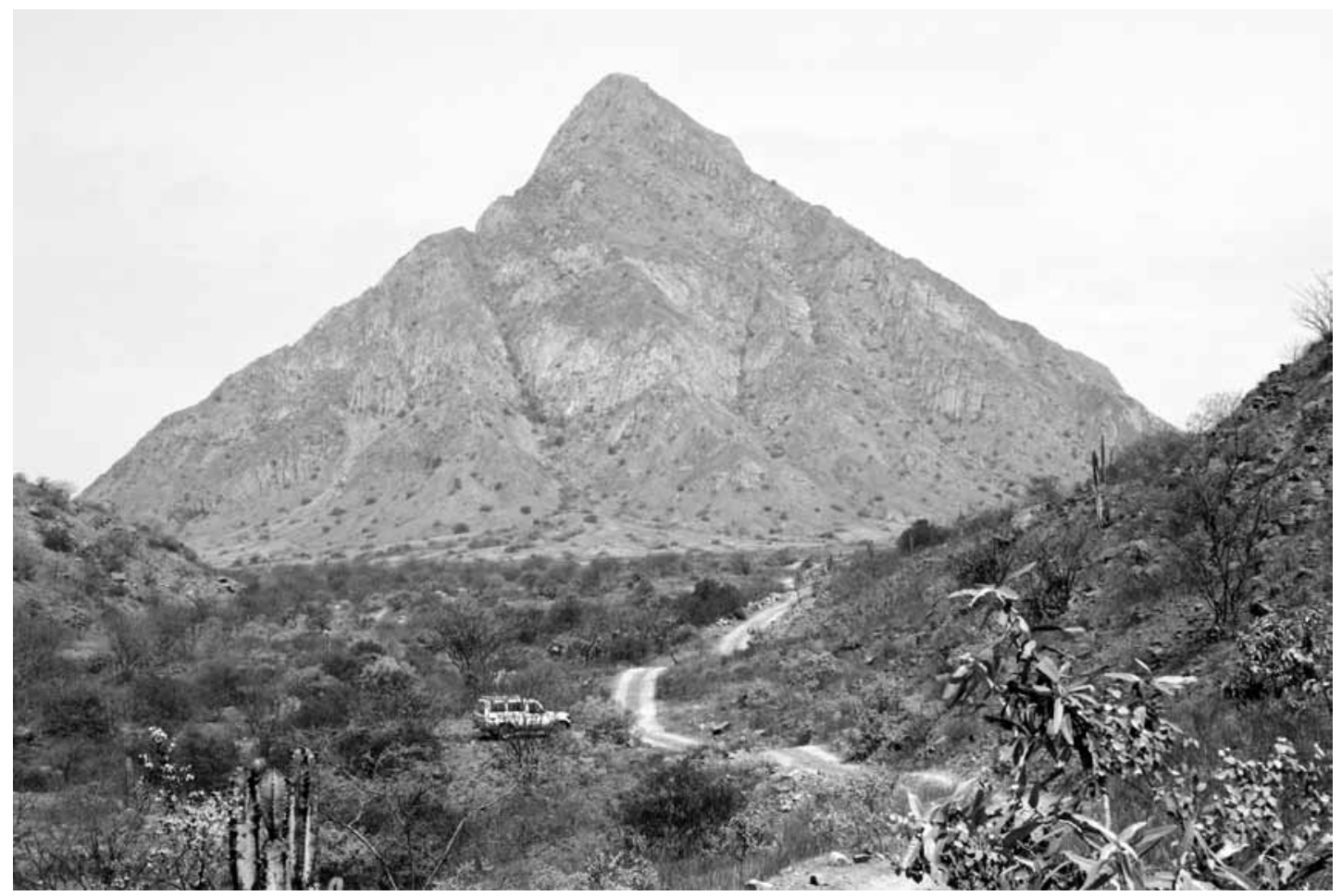

Figure 6. Cerro Cóndor, the distinctly shaped Cretaceous igneous intrusion responsible for mineralization found at Barranco Colorado and Cerro Mellizo. Looking southwest. Photo by Izumi Shimada.

Cerro Cóndor, la intrusión igneacretácea con forma particular causante de la mineralización identificada en Barranco Colorado y Cerro Mellizo. Mirando hacia el suroeste. Foto de Izumi Shimada. 


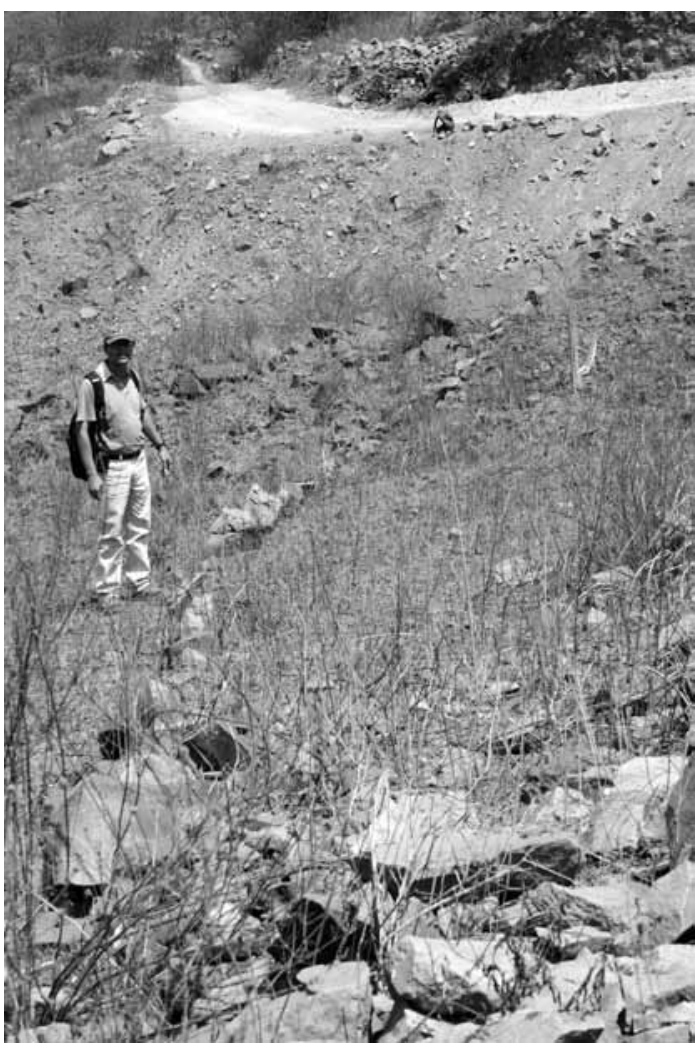

Figure 7. A wall that defines one side of an ancient road to the pre-Hispanic Cerro Mellizo mine. Note a modern road for vehicular traffic cut through the ancient road. Looking northwest. Photo by Izumi Shimada.

La pirca baja que delimita los bordes de un camino antiguo que dirige a la mina de Cerro Mellizo. Nótese que un camino moderno para vehículos cruza el camino antiguo. Mirando hacia el noroeste. Foto de Izumi Shimada.

Airphotos were also valuable for locating ancient roads. In these images, we sought seemingly anomalous, but carefully prepared ancient roads (Figure 7) heading usually to uninhabited mountainous areas. The presence of such roads is perhaps the single most conspicuous archaeological indication of pre-Hispanic mining. This method is advantageous as field tracing of such roads can reveal not only mines and processing sites at their termini, but also empty stone enclosures that could have served as corrals for ore-carrying llamas and smaller stone structures with utilitarian sherds that we believe functioned as roadside camps. At the same time, as with various aspects of ancient mining, it is difficult to securely date these roads (see below). Probably the best means, as just discussed, is through artifacts and architecture found along and at the termini of the road. For example,
Road 4 in Figure 3 connecting the Cerro Blanco mine with the Sicán smelting centers of Cerro Huaringa and Cerro Sajino, although in part used by modern miners, is associated with a petroglyph of the Sicán Deity head, an inferred llama coral, Spondylus princeps offerings, and paleteada (paddlestamped) and other pre-Hispanic sherds. Different portions of Road 6 display divergent construction techniques and widths (including a segment literally paved with pre-Hispanic sherds) that may reflect different work groups.

The Cerro Mellizo mine (Figure 8) is accessible by well-established, predominantly east-west running Road 2 (see Figure 2) that continues to the major site of Túcume (Middle Sicán to Inca periods, AD 1,000-1,532; Heyerdahl et al. 1995; Shimada 2000). At the north base of Cerro Condor, it intersects Road 3 that runs north-south. Farther north of the intersection, Road 3 in turn intersects the east-west running Road 4 that leads to the extensive Barranco Colorado mine (see below). Slightly north of this intersection, Road 3 bifurcates with Road 5, the east branch, heading to the Co. H-S. Complex.

At the east base of Cerro Condor, the aforementioned Road 2 from the Cerro Mellizo mine connects to Road 6, a wide road that runs northward to the Co. H-S Complex along the west margin of the Pampa de Chapparí (Figure 2). Traffic on this road could easily have supplied ores to at least two (Sites 256A01 and 81C10 at the north and south ends of the Pampa, respectively) -and perhaps even six- Middle Sicán smelting sites that were recently identified in the Pampa de Chaparrí (Hayashida personal communication, 2010).

For the pedestrian surveys, we adopted the methods used by traditional prospectors (cateadores) working in arid regions. We interviewed local inhabitants, particularly goat and cattle herders, as they routinely combed through the countryside looking for pastures, water sources and/or their animals. The idea was that they might have encountered mineralized areas (e.g., ore veins), pits or shafts and/or associated talus of gangue that differed from the surrounding landscapes, and/or "floats" or ore fragments in dry streambeds. Showing them examples of ores in which we were interested often helped to stir their memories. It is critical to respect the knowledge of local inhabitants.

In addition to informants, an effective, timehonored method is surveying for floats (ore fragments that washed downstream). We searched streambeds 




Figure 8. The east slope of Cerro Mellizo that was extensively altered by ancient mining. Note the remains of ancient workings still visible on the slope. Photo by Izumi Shimada.

La ladera este de Cerro Mellizo extensamente alterada por la explotación minera antigua. Nótese las perforaciones resultantes de la explotación antigua en la ladera. Foto de Izumi Shimada.

for floats that indicate the presence of minerals of interest somewhere upstream. As one moves upstream closer to the parental outcrop, the float becomes coarser, more jagged and fresher as it is more recently eroded and has traveled less distance. Most of these ore sources in our study area are rather large quartz veins stained by the slow weathering of the pyrites they commonly contain to produce a rusty gossan (an exposed, oxidized portion of a mineral or ore vein). Corrosion of this matrix, in turn, exposes the green and turquoise-blue coatings of secondary malachite and azurite, respectively. Little effort is then needed to expose the underlying crystalline mass of the main ore body.

The above approaches can be creatively combined to best suit a given study situation. Such an adaptable, multi-strand approach is essential to identify the localized, limited landscape changes associated with small-scale, non-mechanized, highly selective pre-Hispanic mining. We are fortunate that these ancient workings in our study area have not been destroyed. Modern mining companies have largely written off much of the north coast from their exploitation as lacking the necessary large tonnage copper porphyry-type deposits suitable for large-scale open pit mining and often containing undesirable arsenic. As discussed later, the presence of the weathered, oxidized form of arsenopyrite (FeAsS) known as scorodite $\left(\mathrm{FeAsO}_{4} \cdot 2 \mathrm{H}_{2} \mathrm{O}\right)$, is critical to understanding local copper arsenic alloy production. At the same time, it should be kept in mind that, even when a mine is identified, the high-grade ore deposits may have been long ago exhausted.

\section{Dating Pre-Hispanic Mines}

As already noted above, dating of mines/mining activity is one of the greatest challenges facing Andean archaeometallurgy. The general scarcity of reliably datable features and material remains at mines, both artifactual and organic, as well as disturbances by Colonial and/or recent exploitation necessitate reliance on negative and broader contextual evidence. The discoveries such as the well-preserved pre-Hispanic tools with the famous 
"Copper Man" of Chuquicamata on the north coast of Chile (Bird 1979; Fuller 2004; Mead 1921) and diagnostic ceramics and radiocarbon-datable materials at the La Primavera hematite mine in backpart of the Ingenio Valley between Palpa and Nasca valleys on the south coast of Peru (Vaughn et al. 2007) represent rare, fortuitous occurrences. Other relative dating means besides diagnostic artifacts and architecture are discussed below.

The principal working (east slope) of the Cerro Mellizo mine (Figure 2), in spite of extensive modern mining-related disturbances, still preserved a fourlevel terrace complex. The best preserved second and third upper levels each measured ca. $20 \mathrm{~m}$ long, $7 \mathrm{~m}$ wide and 0.5-2.6 $\mathrm{m}$ high with masonry facing. Each level had a row of four standardized rectangular, masonry rooms $(4.5 \times 5.3 \mathrm{~m}$ for those on the second level and $4.5 \times 4.5 \mathrm{~m}$ for those on the third level; only their wall bases remain; Figure 9). Although these rooms were free of surface debris (perhaps cleaned by modern miners who set up up camp within them), atop and on the north slope of the low ridge immediately behind and some 5 $\mathrm{m}$ above these structures, we surface-collected the constricted neck of a black Middle Sicán jar as well as fragments of grey Chimú or Chimú-Inca vessels and less diagnostic paleteada vessels. The associated ceramics, then, suggest that pre-Hispanic mining spanned ca. AD 1,000-1,532.

The standardized rooms are quite similar in size, shape and construction to those connected by a walled road to the nearby La Plata mine near the village of Chumbenique on the north bank of the Zaña Valley (Figures 2). Here too, associated ceramics suggest a time span from Middle Sicán to Chimú or Chimú-Inca periods. The standardized structures at both mines, however, suggest Chimú or Inca affiliation and may have served as storerooms.

An additional line of evidence pointing to the pre-Hispanic date of the Cerro Mellizo mine is our discovery of two large Spondylus princeps fragments near an ancient pit. Luis Suarez (personal communication, 1984) reports finding a cluster of some 20 buried Spondylus princeps shells at a nearby location in 1982, prior to the historic 1983 El NiñoENSO event that badly eroded the area. S. princeps, a thorny oyster with striking pinkish-red or orange colored flesh and shell is derived from the tropical

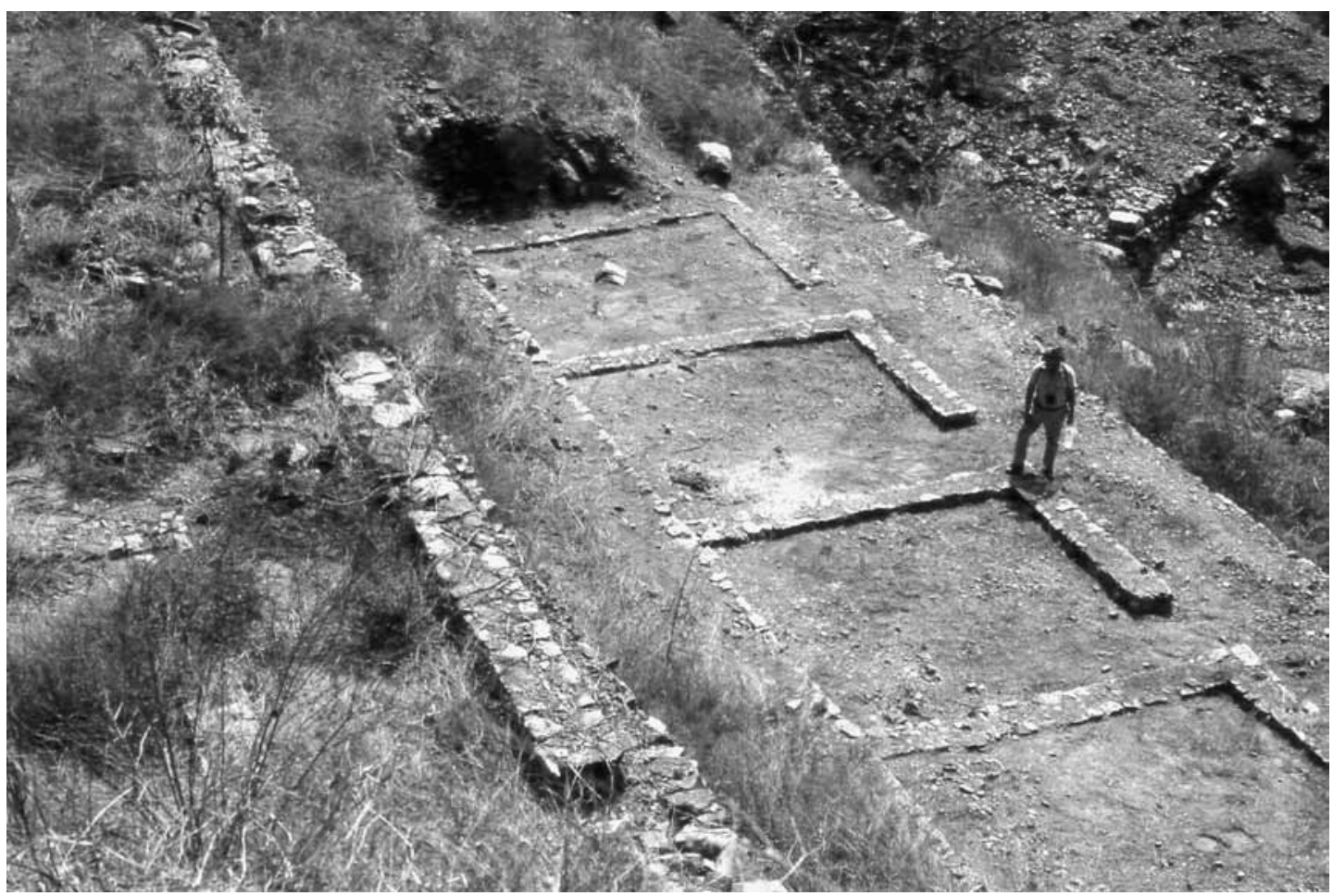

Figure 9. Four-level terrace complex with standardized masonry rooms at the west edge of the Cerro Mellizo mine. Looking north. Photo by Izumi Shimada.

El complejo de terrazas en cuatro niveles con cuartos rectangulares estandarizados de mampostería ubicado en la margen occidental. 
sea along the Ecuadorian coast and farther north and was long used throughout the Andes as an important offering. Artistic representations and colonial-era documents both point to shell's symbolism related to water and fertility (e.g., Carter 2008; Glowacki 2005; Paulsen 1974). "The Huarochirí Manuscript", a Quechua folklore/religious account (Andean religion as opposed to Inca religion) recorded in its original language sometime at the beginning of the 17th century relates that the mullu, large tropical marine shells including Spondylus sp., are the favorite food of deities who reside in mountains and other sacred locations (Salomon and Urioste 1991). The Spondylus offering we documented at the Cerro Mellizo mine, then, may have constituted a "payment" or "appeasement" to the supernatural beings who governed the Cerro to allow the miners to extract ores (see below).

At the extensive Barranco Colorado mine, a working (ca. $1.5 \mathrm{~m}$ wide, $100 \mathrm{~m}$ long, $>4 \mathrm{~m}$ deep [total depth undetermined yet due to the fill]) that traced a narrow discovery vein (ca. $3.5 \mathrm{~m}$ wide) at the peak of Cerro Barranco Colorado (Figure 10) yielded no datable items. A roughly U-shaped, masonry structure $(>6 \mathrm{x}>5 \mathrm{~m})$ amongst over 30 dispersed open circular and oval pits (ranging from ca. $1.5 \mathrm{~m}$ across and $1 \mathrm{~m}$ deep to $30 \times 13 \mathrm{~m} \mathrm{x} 4 \mathrm{~m}$ deep) on the west slope of the Cerro was associated with a batán (large anvil stone for crushing ores and/or slag; $0.68 \times 0.45 \mathrm{~m} \times 0.25 \mathrm{~m}$ high) and pre-Hispanic ceramics that together suggest a time span similar to that of the Cerro Mellizo mine.

Careful examination of tool marks in mines provides additional chronological clues. The stone hammers used by pre-Hispanic miners leave blunt edged peck marks (sometime with some crushed ores still adhered) that contrast with the sharper edged marks that modern steel tools leave. Removal of high-grade ore by carefully tracing veins inevitably results in irregularly shaped workings. On the other hand, spacious adits (nearly horizontal accesses to mines), winzes (vertical or steeply inclined shafts between different levels in a mine for access and/ or ventilation), and stopes (step-wise excavations to extract ore from steeply inclined veins) suggest Colonial and/or more recent mining (Shimada 1994a).

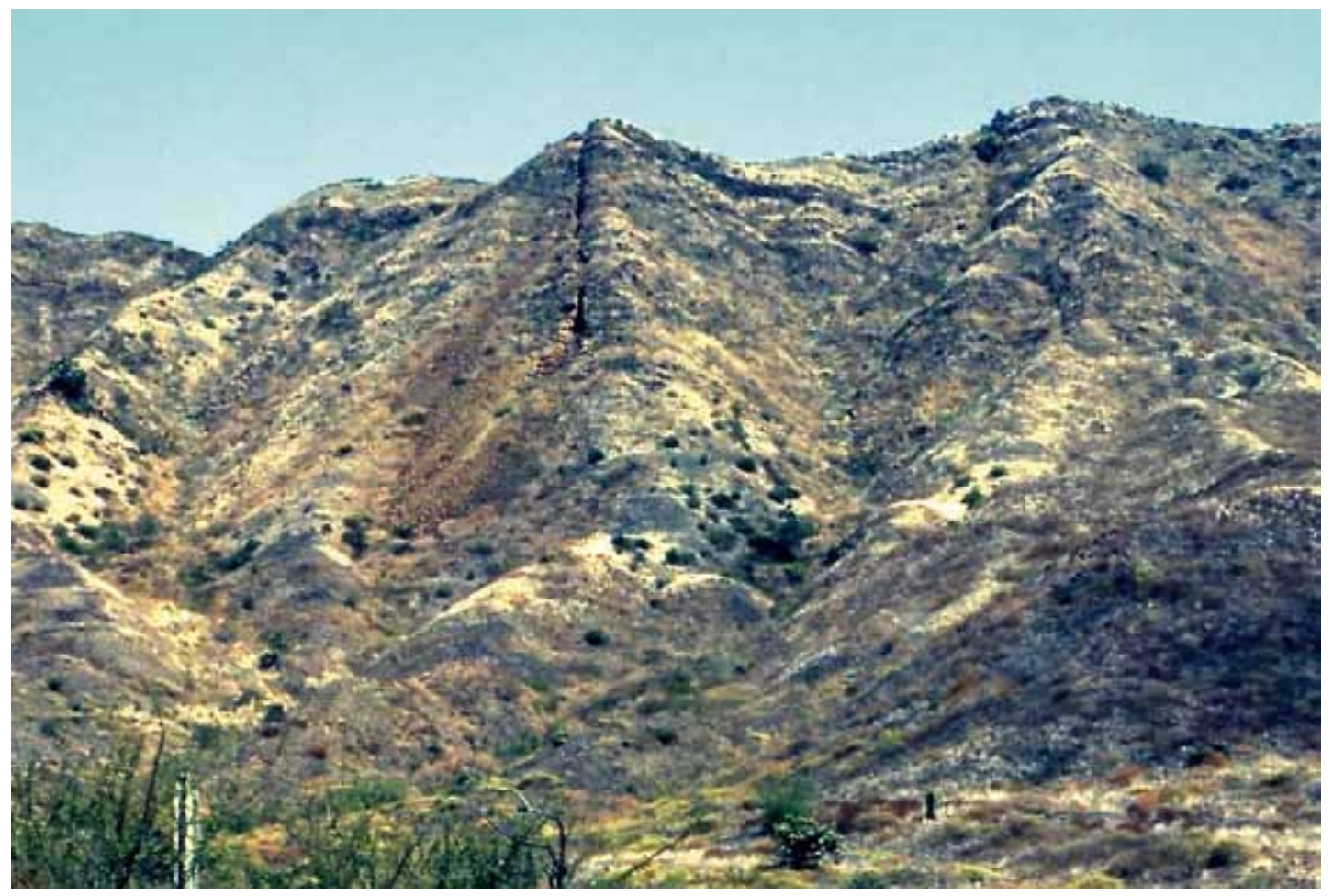

Figure 10. Narrow pre-Hispanic working atop Cerro Barranco Colorado and associated tailings (to the left of the mine). Looking southwest. Photo by Izumi Shimada.

La mina angosta encima de Cerro Barranco Colorado y los restos de minerales desechados (a la izquierda de la mina). Mirando hacia el suroeste. Foto de Izumi Shimada. 
Additionally, we should maximize any organic debris inside mines including soot accumulations (torches for lighting or fire-setting or fire-quenching) for AMS-dating and a minimum age of mines.

Again, our best approach to reliable dating appears to be multi-pronged and opportunistic.

\section{Sicán Mining: Case Study at the Cerro Blanco Mine}

The Cerro Blanco mine deserves special attention here for the insights it affords us on Sicán mining (Shimada 1994a; Shimada et al. 1982). Our understanding is most complete for this mine, which is one of the largest we have documented so far in the study area. The mine was also repeatedly worked during the historic past, and even into the present on a sporadic basis. This continuing activity is evidence that the deposit was unusually rich and extensive. Megascopic and microscopic examination of ore samples collected at two prospecting pits and the inferred principal pre-Hispanic working indicates the presence of high-grade malachite, $\mathrm{Cu}_{2} \mathrm{CO}_{3}(\mathrm{OH})_{2}$ as well as a variety of weathered but high-grade (up to $25 \%$ concentration) copper sulfides, particularly chalcopyrite, $\mathrm{CuFeS}_{2}$, and to a lesser extent, bornite, $\mathrm{Cu}_{5} \mathrm{FeS}_{4}$, and arsenopyrite, FeAsS.

Together with the Cerro Mellizo and the Barranco Colorado mines, Cerro Blanco was most likely one of the principal ore sources for the nearby smelting sites of Cerro Huaringa, Cerro Sajino, Huaca del Pueblo Batán Grande (Figure 11) for much of their existence spanning the Middle Sicán period to the time of the Spanish Conquest.

The Middle Sicán origin of the Cerro Blanco mine is indicated not only by the initiation of the copper-arsenic alloy smelting at Huaca del Pueblo Batán Grande (Shimada 1985a,b; Shimada and Merkel 1991) and most likely Cerro Huaringa, but also by the presence of a petroglyph of the diagnostic Sicán Deity face (Figure 12) along the road (Road 1) that connected the mine with the Co. H-S Complex. This road was later improved as part of the systematization and expansion of metallurgical production instituted at the Complex soon after Chimú conquest of the Sicán polity at the end of the 14th century

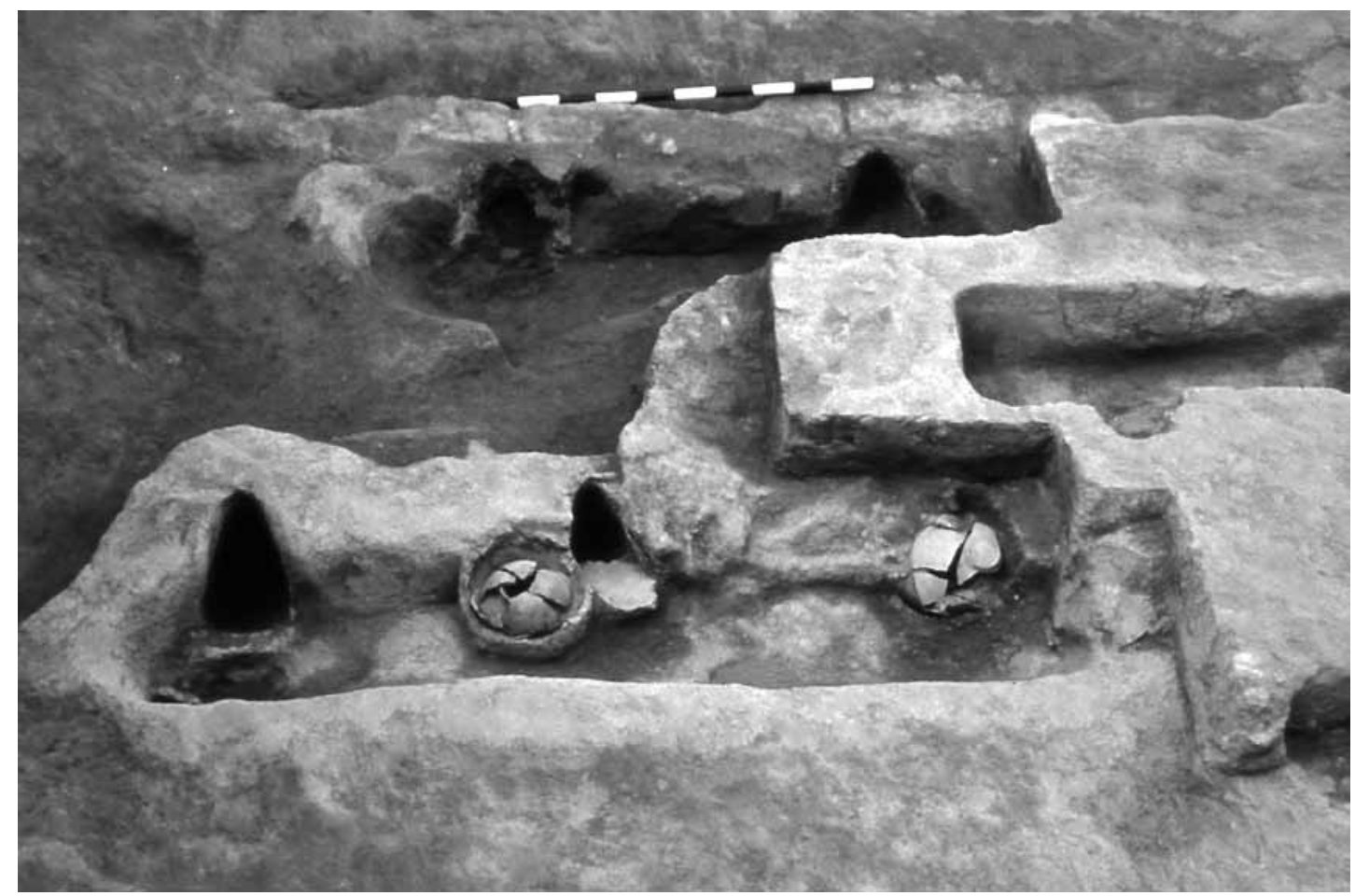

Figure 11. Middle Sicán smelting workshop at Huaca del Pueblo Batán Grande showing three superimposed sets of smelters. Note offerings placed near and atop the abandoned smelters. Looking northwest. Photo by Izumi Shimada.

El taller de fundición Sicán Medio en el sitio de Huaca del Pueblo Batán Grande señalando los tres conjuntos superpuestos de hornos de fundición. Nótese las ofrendas puestas cerca y encima de los hornos abandonados. Mirando hacia el noroeste. Foto de Izumi Shimada. 


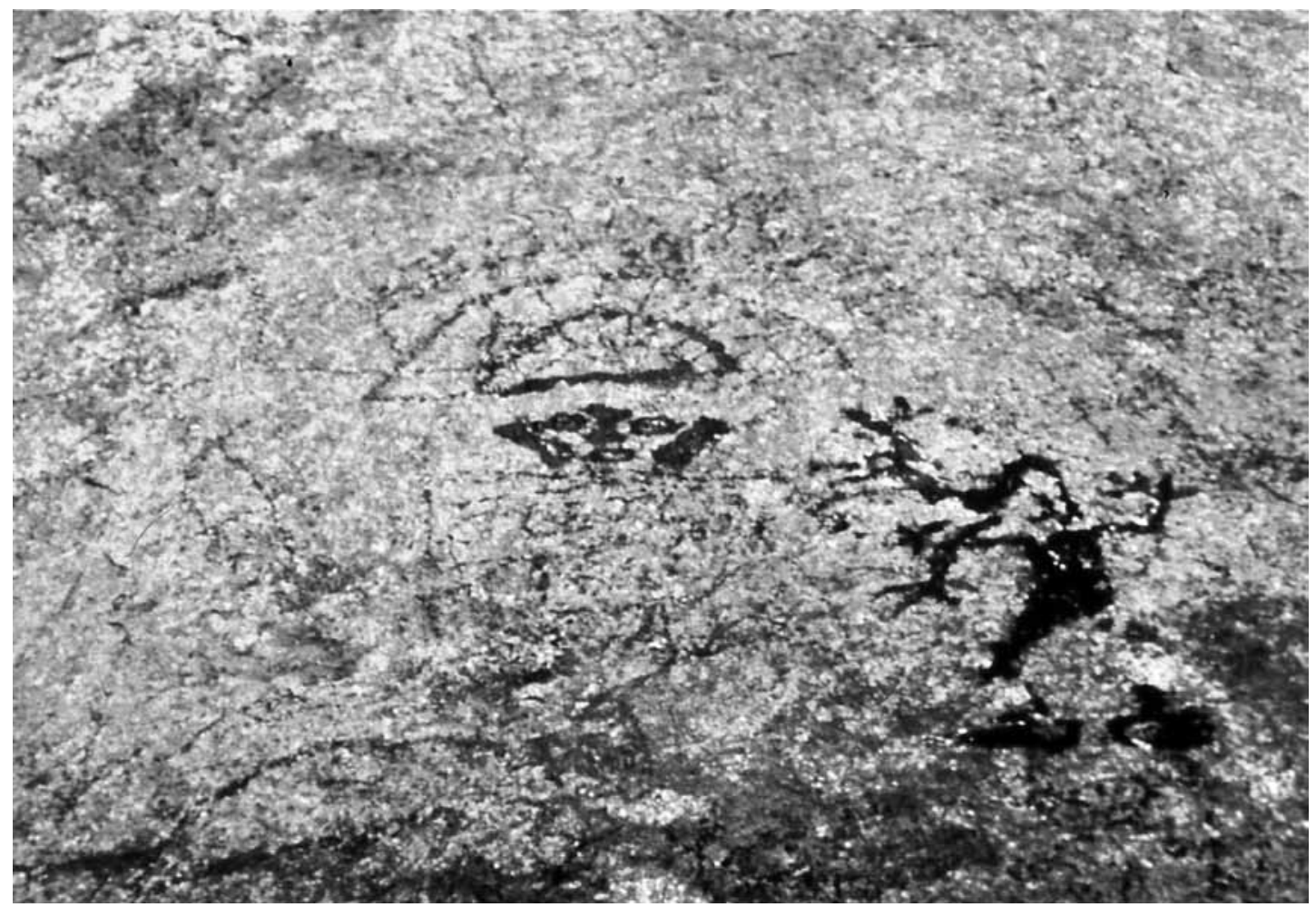

Figure 12. Petroglyph of the Sicán Deity figure (his face measures roughly $18 \mathrm{~cm}$ wide and $10 \mathrm{~cm}$ high) on a boulder at the north base of Cerro Blanco close to the ancient road connecting the mine and the Cerro Huaringa and the Cerro Sajino smelting sites. Photo courtesy of Juan Carlos Santoyo.

El petroglifo representando el Dios Sicán (su cara mide aproximadamente $18 \mathrm{~cm}$ de ancho y $10 \mathrm{~cm}$ de altura) grabado en una peña en la base norte de Cerro Blanco. Está ubicado cerca del camino antiguo que conecta la mina de Cerro Blanco por un lado y los sitios de fundición de Cerro Huaringa y Cerro Sajino. Foto cortesía de Juan Carlos Santoyo.

(Epstein and Shimada 1984). For much of its length, the elevated road had stone-faced embankment and was wide enough to accommodate llama caravans (Shimada and Merkel 1991). In our 1979 survey of the road, we found six whole Spondylus princeps shells that had eroded out of embankments, clearly attesting to the symbolic importance of the integrated mine-metallurgical complex.

Ore extraction at the mine started at the discovery-vein which radiated out from Cerro Blanco with a vertical dip and strike of $90^{\circ}$. Not a vestige of mineralization remains in this narrow trench (Figure 13) that slices through highly metamorphosed cherty limestones and shales now altered to marbles, phyllites, and hornfels. This vein pinched out at shallow depth and was abruptly terminated a few meters within the adjacent hillside by a major transverse fault and gouge zone, both of which were also mineralized.
Sicán miners removed the ore, most likely to have been malachite, from the $25 \times 3 \times 9 m$ discovery vein entirely by hand, leaving the cajas (barren country rock walls) completely clean and undisturbed. A similar trench-like caja characterized the nearby Cerro Barranco Colorado mine (Figure 10). Hanging wall surfaces are quite clean and geometrically shaped surfaces are absent. There are no indications that fire-quenching was employed at either mine. Thus, we suspect that the vein and ore material were deeply weathered and friable.

The discovery-vein trench was followed along its length to the abrupt end created by a large concentric fault roughly parallel to Cerro Blanco. Prehistoric miners followed this new and even larger vein, probably in both directions, although only one side now remains relatively undisturbed by later exploitation. Again, there is nothing to suggest that they used any special tools or techniques 


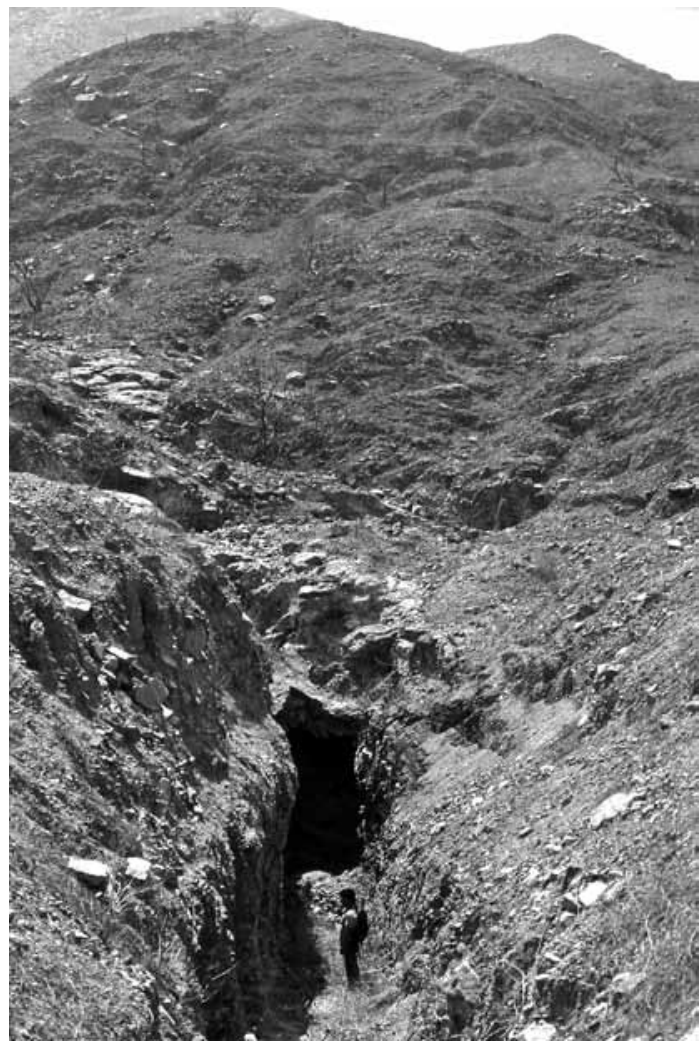

Figure 13. Trench left behind after removal of the discovery vein at the Cerro Blanco mine. Looking east. Photo by Izumi Shimada. Una zanja grande que resultó de la explotación antigua de la veta ("discovery vein") en la mina de Cerro Blanco. Mirando hacia el este. Foto de Izumi Shimada.

distinct from those found with the "Copper Man" of Chuquicamata.

Inside prospecting pits and larger workings at Cerro Blanco, we found roughly triangular and oblong stones $(17-22 \mathrm{~cm}$ long, $9-13 \mathrm{~cm}$ wide, and $3-6 \mathrm{~cm}$ thick), resembling the "hammers" found associated with the "Copper Man" (Bird 1979:114, his Figure 4). The battered apices of the triangular stones and their heavy weight (around $0.5 \mathrm{~kg}$ ) support the notion that at least some of them served as picks or hammers to crack or batter ores into small pieces that could then be collected in bags or baskets much as Copper Man did. Wedges, pegs, and levers made of algarrobo (Prosopis pallida) or other hardwood (palm tree heart?) and/or of hardened copper arsenic alloys may have been employed to pry loose larger ore fragments. We have, however, no supportive physical evidence of their use other than associated river cobbles that could have served as hammers to drive them into ore bodies.
Today, the Cerro Blanco mine consists of three levels developed along a concentric mineralized vein, plunging at $41^{\circ}$ toward the intrusive stock. Several large stopes and winzes have been opened in connection with these levels and it is doubtful they represent pre-Hispanic workings. If Sicán and other pre-Hispanic miners did, in fact, follow the complex ore shoots, more recent exploitation have obliterated traces of their efforts.

Identifying and estimating the quantity of ore removed from the pre-Hispanic mines we have examined in the study area is a difficult task; at Cerro Blanco, Cerro Mellizo and a few other mines, nothing diagnostic was left behind to indicate the type and richness of the ore they removed. Additionally, we suspect that the bulk of relatively less accessible ores that had remained at the mine was taken out during historic times. At the same time, if we arbitrarily assign a conservative mean grade of 3-4\% of copper oxide to the Cerro Blanco ore body, we believe its copper production alone is sufficient to account for much of the copper and copper alloy artifacts curated in all museums on the Peruvian coast with which we are familiar.

\section{Characterizing Sicán and Late Pre- Hispanic Mining in the Lambayeque Region}

Based on our investigation of six pre-Hispanic mines in the study area (Table 2), we offer the following characterization of late pre-Hispanic mining in the Lambayeque region:

1. Mining focused on ore deposits at or near the surface, carefully following and thoroughly removing them, leaving behind open pits that matched exactly the shape of the original ore body, regardless of size. Mine interior shape, size, and orientation are generally irregular or sinuous as dictated by the ore deposits that were removed, a conclusion identical to that reached by Craddock (1995:31) for the early mines of Europe.

2. Mining targeted secondarily enriched, high-grade oxide ore bodies, small and large (mostly in the form of high-grade malachite $\left(\mathrm{Cu}_{2} \mathrm{CO}_{3}[\mathrm{OH}]_{2}\right.$; up to $25 \%$ copper in weight (Merkel et al. 1994) as well as arsenopyrite [FeAsS], and a variety of weathered copper sulfides, chalcopyrite $\left.\left[\mathrm{CuFeS}_{2}\right)\right]$ ) resulting in tailings that are relatively small in size and volume. Weathered arsenopyrite near the surface was noted at 


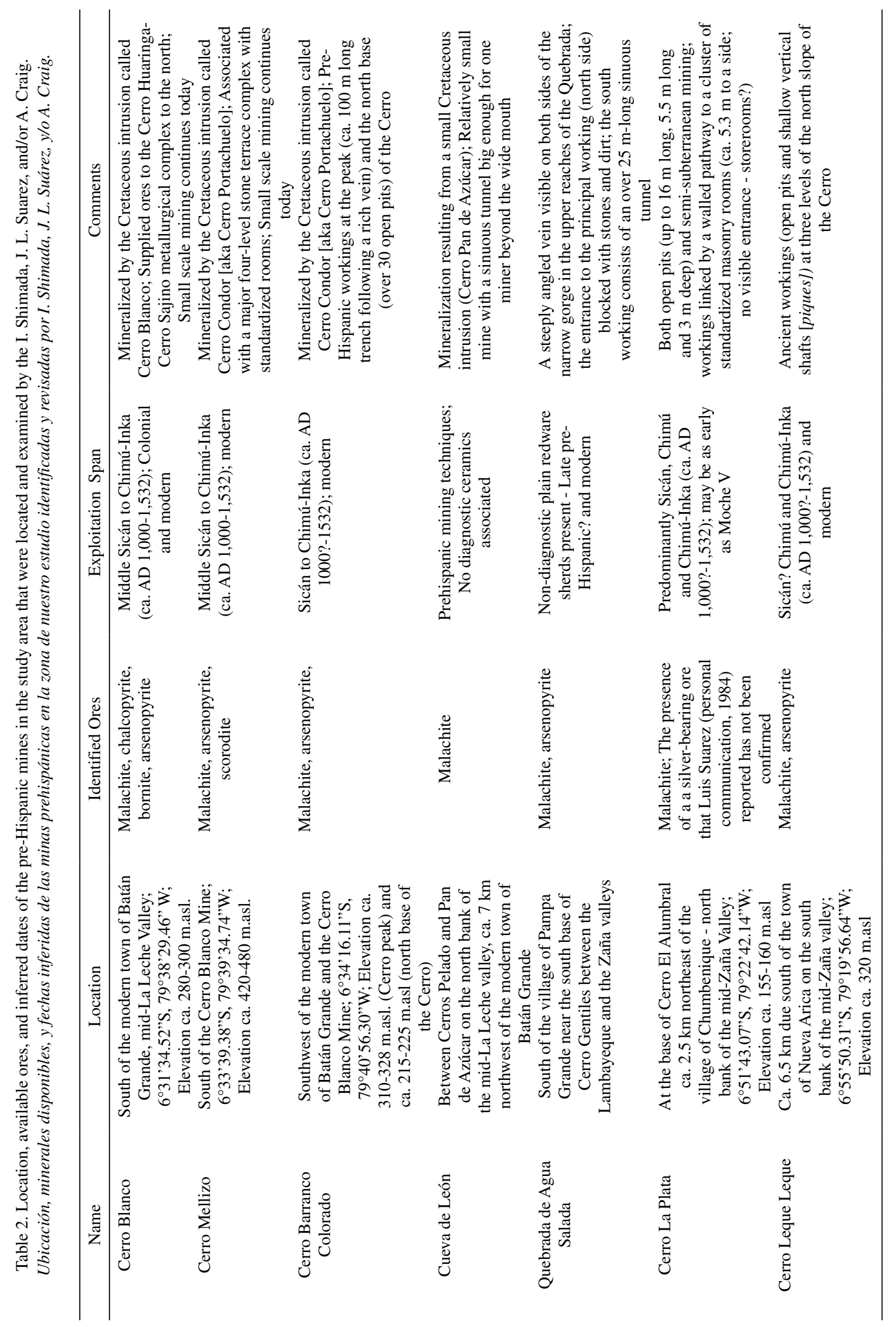


various mines including Cerro Mellizo and Cerro Leque Leque (Zaña Valley; Fig. 2), while chalcopyrite was available at Cerro Blanco.

3. Mines penetrated less than $10 \mathrm{~m}$ in vertical depth (no definite stopes) and up to $100 \mathrm{~m}$ horizontally with discontinuous concentrations worked by means of separate, shallow pits as at Cerro Barranco Colorado and Cerro La Plata.

4. Well-developed roads (some with embankment, wall borders and/or some pavement [including use of sherds for the purpose]) that would have accommodated llama caravans provided access to mines.

5. Ore extraction relied on a limited range of elementary stone tools with triangular hammers (perhaps hafted?) being the most essential as miners focused on weathered and friable (thus easily extractable) ore bodies. Distinctive peck marks were noted on wall faces at various mines. Given that ore extraction did not require much technical expertise once the target deposit was identified, the task could have been performed by conscribed non-specialists, although it would have been physically taxing wielding heavy stone hammers.

6. We found no conclusive evidence of fire-setting or fire-quenching (e.g., charcoal and ash on the mine floor, heat-alterations on mine interiors, and/or relatively smooth mine wall surfaces resulting from the exfoliation of heat-fractured layers) that would have facilitated extraction by shattering and fracturing the exposed ore bodies. Although the subsequent extraction of the desired ore from areas affected by firesetting or fire-quenching may have removed much of the above lines of evidence, we would expect at least to find some easily identifiable evidence. Yet, we did not find any.

7. Provisions for light, ventilation, drainage, and safety were generally lacking, although the arid conditions of the region minimized problems of water seepage.

8. Torches may have been used for light as soot was noted on the ceilings of some mines.

9. Evidence for a regular supply of provisions including water, on-site food preparation, and protective shelters for workers at mines is scant. Given that the mines we located were all within a day's walk to at least one smelting site, mining may well have been conducted on a commuting basis. Simple rectangular masonry structures adjacent to or near workings found at large mines (Barranco Colorado, Cerro Blanco, Cerro La Plata, and Cerro Mellizo) could have provided short-term resting places for workers and/or storage for mining and beneficiation equipment as well as extracted ores waiting to be transported. These structures need to be excavated to properly test the above inferences.

10. Initial ore beneficiation was conducted near each mine, although it was minimized by the highly selective nature of their mining and use of blunt tools that tended to crush or break up ores into relatively small usable pieces (thus leaving only small gangue piles and/or taluses).

11. Final ore beneficiation was performed at smelting sites using batán-chungo sets (Figure 14; a large stable anvil and a heavy, companion rocking stone) that efficiently crushed ores into tiny pieces, facilitating quick hand and visual sorting.

12. Last - but by no means the least important -was the widespread symbolic importance of mines

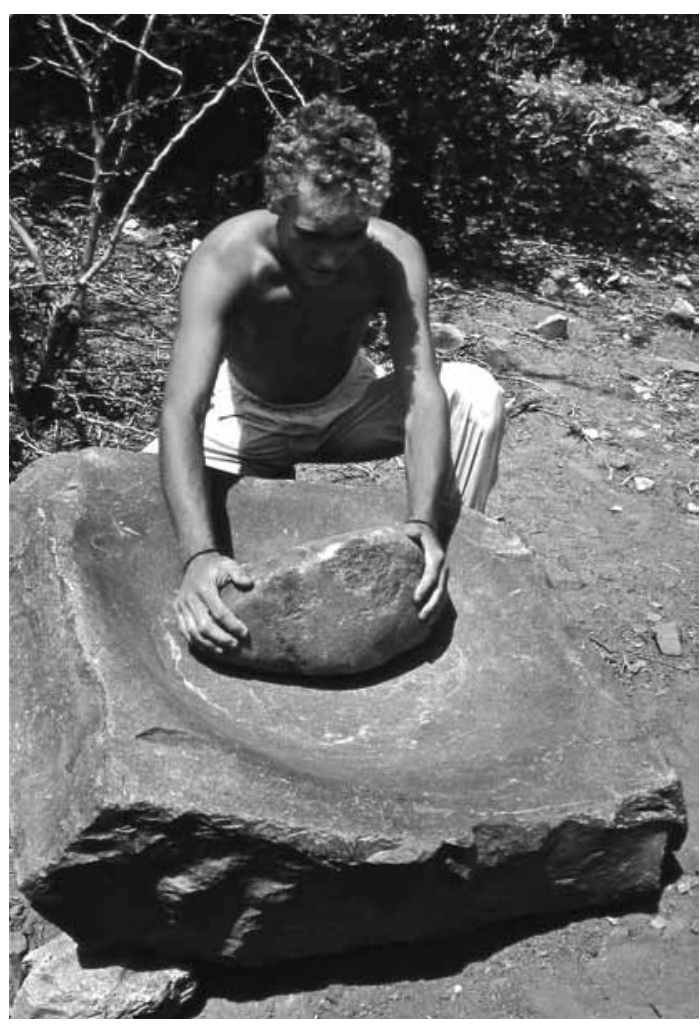

Figure 14. A batán-chungo set used for crushing ores and slag at Sector III, Cerro Huaringa. Photo by Izumi Shimada.

Un conjunto de batán y chungo utilizado para triturar minerales y escoria en el Sector III, Cerro Huaringa. Foto de Izumi Shimada. 
(mines as huacas or sacred places or entities) or belief in the supernatural power of mines. Offerings of mullus (e.g., Spondylus princeps) placed at workings and along roads suggest the sanctity of mines and extracted ores. The aforementioned presence of the petroglyph of the Sicán Deity at the north base of Cerro Blanco (Fig. 11) is particularly noteworthy is this regard. Ethnohistorical sources offer strong support of the preceding view (Ramírez 1994:95-96).

Overall, Sicán and later pre-Hispanic metal mining in the Lambayeque region of the north coast of Peru was technically simple, labor intensive, and focused on readily accessible outcropped, weathered and enriched, high-grade oxide, carbonate and sulfide ore bodies bearing copper and arsenic (arsenopyrite and scorodite). The Sicán opted for a spatially dispersed mining pattern that exploited all accessible sources and thus the scale (and perhaps intensity as well) of mining varied according to the size and extent of the ore body. As discussed below, our holistic investigation of mines and associated smelting sites has shown that Sicán copper-arsenic alloy production was essentially autochthonous and based on local ores supplied by mines of varied size within a day's walking distance.

\section{Mining-Metallurgy as an Integrated System: A Holistic Vision}

\section{Sicán copper-arsenic alloy production: local ores and co-smelting}

In the preceding sections, discussion about dating mines, identifying extracted ores, the intensity and organization of mining, and the roads that interconnected specific mines and smelting sites all illuminated the importance of coordinated investigation (i.e., holistic approach) of both mines and smelting sites to gain an overall understanding of the system these constituted. Perhaps the most instructive case demonstrating the value of the holistic approach is its contribution toward resolving the nature of smelting charge used in the Sicán metallurgy that produced copper arsenic alloys with typical arsenic concentrations of 1 to $5 \%$ by weight.

It has been long debated whether pre-Hispanic metallurgists successfully smelted sulfarsenide ores such as arsenopyrite (FeAsS), orpiment $\left(\mathrm{As}_{2} \mathrm{~S}_{3}\right)$ and realgar (AsS) by first roasting them to eliminate sulfur to produce these alloys and, if so, the sources of these ores (Caley 1973; Caley and Easby 1959; Lechtman 1979, 1981, 1991, 1996; Lechtman and Klein 1999). Caley (1973) interpreted the presence of arsenic in Sicán objects as indirect evidence that sulfide ores were being smelted. Lechtman (1979, 1991) argued that the idea of deliberately producing this type of bronze on the north coast was a cultural innovation introduced along with highland arsenicbearing ores at the time of the highland-based Wari expansions around AD 600-850.

As noted earlier, however, some Moche ceremonial and ornamental copper objects dating to as early as AD 200-300 from Dos Cabezas and Moche in the Jequetepeque and the Moche valleys, respectively (Donnan et al. 2008; also see Kroeber 1954), contain variable and generally low concentrations of arsenic, raising the possibility that Moche metallurgists were either unable to effectively control the alloy process or produced copper-arsenic alloys unintentionally, perhaps through co-smelting of copper oxide and arsenic-containing sulfide (e.g., arsenopyrite; emphasis added) ores (Bezúr 2003; Rostoker and Dvorak 1991; Lechtman and Klein 1999).

Pursuing rich outcropped copper oxide ores, Moche and later Sicán miners may well have inadvertently tapped into underlying sulfarsenide ore bodies or nearby oxidized forms of arsenopyrite (Bezúr 2003). The preceding data and argument, together with the absence of imported arsenicbearing ores such as realgar and orpiment at any of the Sicán smelting sites we excavated or surveyed, question the earlier argument of externally derived sulfarsenide ores and smelting technology. Orpiment and realgar are visually quite distinct and easily recognizable, having a golden to orange-yellowish and a reddish color, respectively.

To the contrary, our analyses of primary context samples of ore and smelting products and byproducts recovered at smelting sites such as Huaca del Pueblo Batán Grande have shown that copper-arsenic alloys were deliberately and locally smelted and that arsenic was derived partially, if not predominantly, from scorodite available at the large Cerro Mellizo mine (Merkel et al. 1994; Shimada and Merkel 1991) and quite likely at other mines in the study area with weathered arsenopyrite. Given that much of the eastern slope of Cerro Mellizo was removed prehistorically in an extensive open pit, we cannot disregard the possibility that large 
quantities of both copper oxide and scorodite ores were extracted from this mine. The presence of matte, a mixture of sulfides formed in smelting sulfide ores, in direct association with smelters at Huaca del Pueblo Batán Grande (Merkel et al. 1994) further supports the aforementioned co-smelting. Together with gradual improvements in the design and construction of smelters and tuyeres (durable ceramic blowtube tips) that we have documented over the span of some 500 years from the beginning of the Middle Sicán (Shimada and Merkel 1991), we believe that, over the same time span, Sicán metallurgists refined the nascent co-smelting technology inherited from their earlier Moche counterparts.

\section{Fire-setting and fuel management}

The holistic approach also illuminated an important issue that has not received much attention in Andean archaeometallurgy: namely, fuel management and fire-setting. The latter involves deliberately setting an intense, sustained fire against the wall face and has been well documented in many ancient European mines (e.g., Craddock 1992). The intense heat causes the ore deposits to both expand and contract as moisture within vaporizes, resulting in their fracture and shattering and facilitating extraction.

We have not found, however, evidence of its application in the study area. The occasional patches of soot on the ceilings of workings we detected appeared to have resulted from torches, not fire-setting. Given that fire-setting would have significantly facilitated mining, particularly with primitive pre-Hispanic stone tools, why this method was not utilized begs consideration. The holistic approach points to the ecological exigencies of the arid environment of our study area and its limited fuel supplies as key considerations.

Our paleoethnobotanical and replicative experimental studies of fuels used in smelting and metalworking clearly reveal careful management of wood and charcoal.

Sicán copper-arsenic smelting was fuel and labor intensive. Our smelting experiments necessitated the continuous labor of three to four individuals providing continuous draft into a small furnace through narrow blowtubes with ceramic tuyeres for roughly three hours to produce slag lumps weighing ca. 700-800g with embedded prills (tiny metallic pieces) (Shimada and Merkel 1991; Figures 15,
16). Approximately $30 \mathrm{~g}$ of copper prills were handretrieved after crushing the resultant slag lump with a batán-chungo set. Each experiment used about $1 \mathrm{~kg}$ of smelting charge prepared from finely ground high-grade malachite ore from the Cerro Blanco mine roughly $30 \%$ in copper concentration in weight combined with an equal part of finely ground, local, high-grade hematite (readily available in outcrops west of Cerro Blanco) as flux, and about $6 \mathrm{~kg}$ of high quality charcoal prepared from a locally available hardwood, algarrobo (Prosopis pallida). If we consider that the furnace had to be preheated prior to smelting and prills had to be further refined and consolidated to produce ingots and preforms, then each smelting workshop equipped with three to five furnaces at Huaca del Pueblo Batán Grande, Cerro Huaringa, Cerro Sajino and other sites could easily have consumed over 30kg of charcoal each day.

Microscopic analysis of charcoal in ceramic kilns, metalworking furnaces, and domestic hearths that coexisted at the ceramic-smithing workshop of Huaca Sialupe (Goldstein 2007; Goldstein and Shimada 2007; Figure 17) further revealed that desirable algarrobo charcoal was reserved for craft production and that residual algarrobo charcoal from ceramic kilns was recycled for working both copper-arsenic and gold alloys. Long-lasting and high-energy yielding algarrobo charcoal was clearly the mainstay of smelting (at Huaca del Pueblo Batán Grande, Cerro Huaringa, Cerro Sajino) and metalworking (at Huaca Sialupe). Well-preserved algarrobo charcoal pieces at the Sialupe workshop that were examined had relatively small diameters and beetle holes and galleries. Apparently, infested and/or dying trees and branches as well as fallen trunks and branches were maximized as fuel rather than harvesting healthy trees.

In sum, our holistic approach points to careful, sustainable utilization of wooden resources. In this sense, the absence of fire-setting or fire-quenching is not an enigma, but instead appears to have been a rational decision that appropriately weighed the ecological exigencies of the arid Lambayeque region and attendant limitations of high quality wooden fuel supplies and the cultural importance of metals.

\section{The style, technology and organization of sicán metallurgy}

We end this paper with a brief discussion of the organizational principles and cultural preferences underlying Sicán mining and metallurgy. 


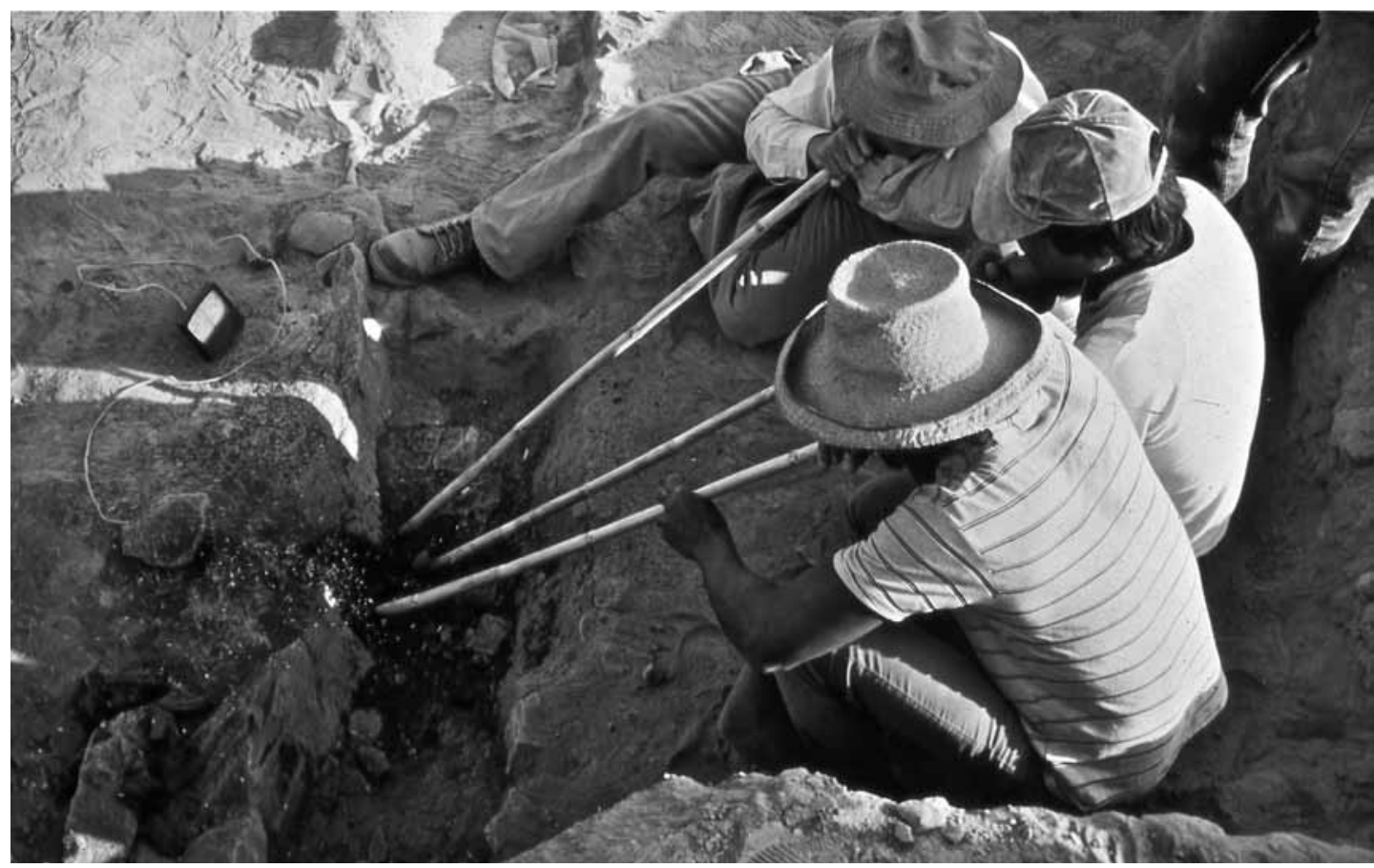

Figure 15. Replicating smelting experiment conducted at the Cerro Huaringa site using a well-preserved Chimú-period smelter. Photo by Izumi Shimada.

Una escena del experimento de fundición realizado en el Sector III del sitio de Cerro Huaringa utilizando un horno de fundición muy bien conservado de la época de la dominación Chimú (siglo XV). Foto de Izumi Shimada.

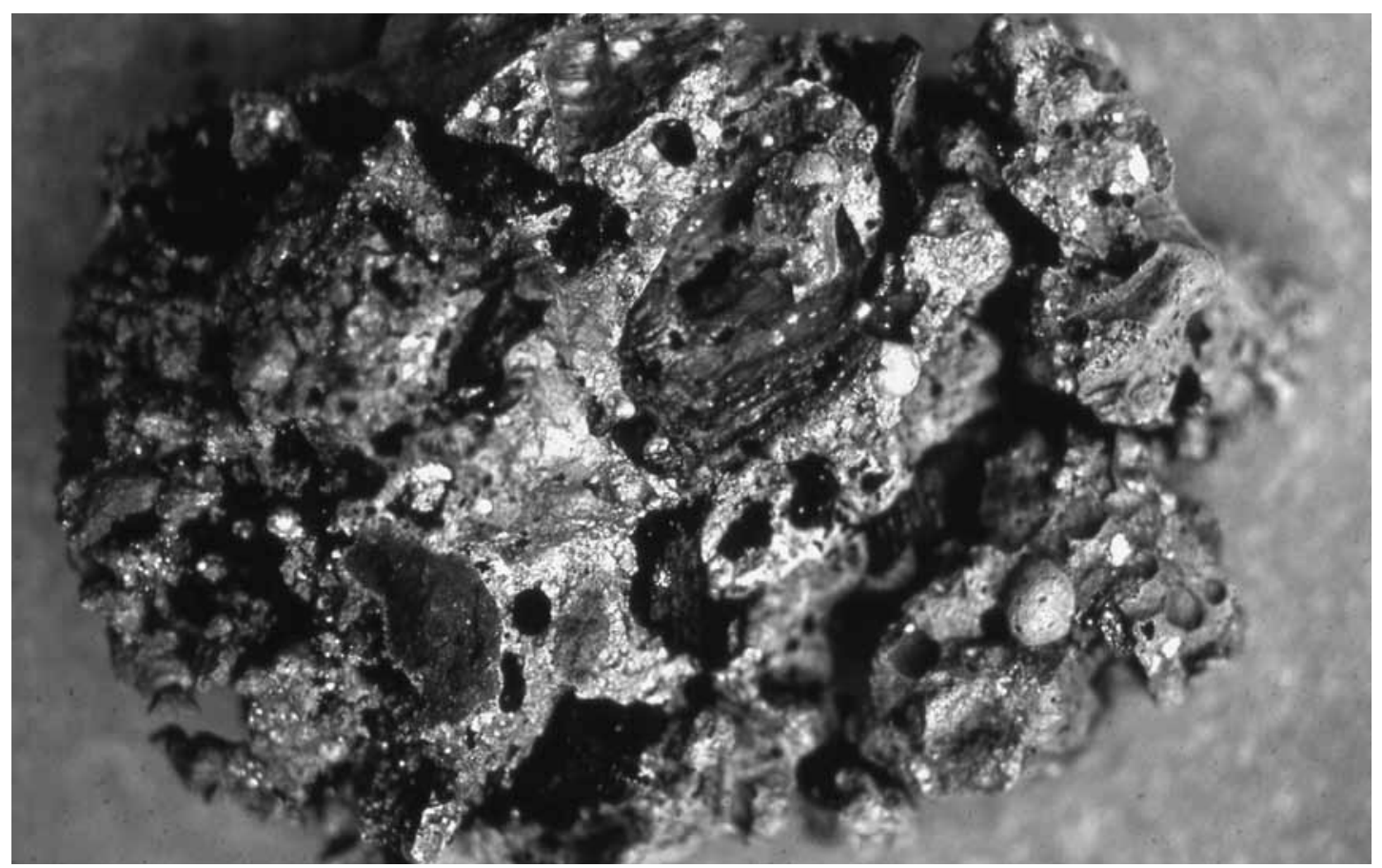

Figure 16. Slag with entrapped prills that resulted from our replicative smelting experiment shown in Figure 14. Photo by Izumi Shimada.

El trozo de escoria con gotas metálicas ("prills") entrampadas de distintos colores que resultó de nuestro experimento de fundición ilustrado en Figura 14. Foto de Izumi Shimada. 


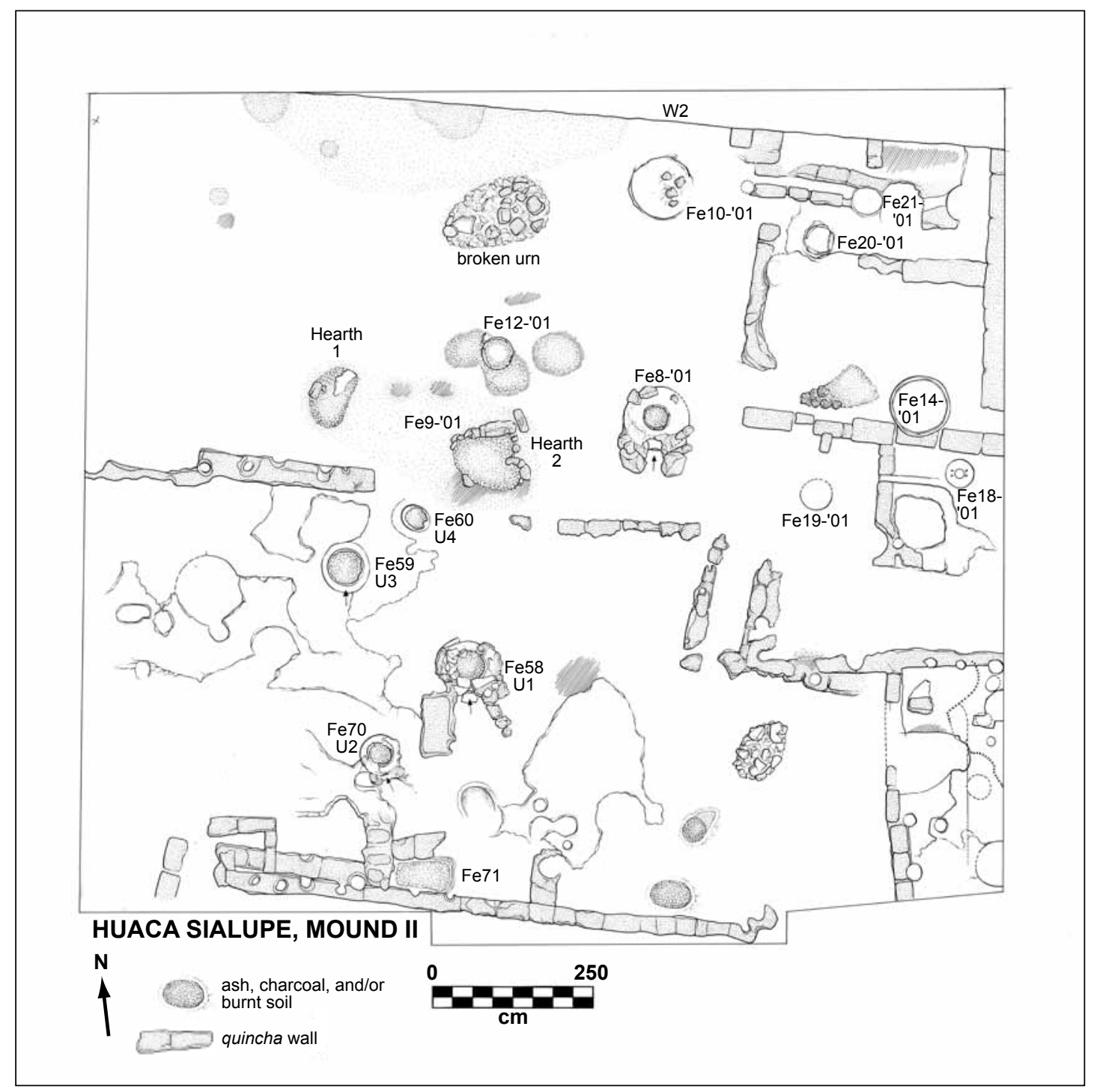

Figure 17. A group of Middle Sicán metalworking furnaces (identified by "Fe") excavated at the east end of the Huaca Sialupe workshop. Drawing by Izumi Shimada.

Un grupo de hornos de metalistería (identificados por "Fe") excavados en el margen este del taller en Huaca Sialupe. Dibujado por Izumi Shimada.

Over the course of the 34 years of the Sicán Archaeological Project, we have excavated four and identified three additional Sicán smelting sites (Figure 2), most in relative proximity to a mine with high-grade copper oxide and arsenic-bearing ores. As noted earlier, the Ynalche Project directed by Frances Hayashida (2009) documented two definite Sicán smelting sites and tentatively identified an additional four within Pampa de Chaparrí. The multiplicity of smelting sites and mines points to "task redundancy on a regional level" (emphasis added; Bezúr 2003:130) or what Shimada (1994a, 2001; Shimada and Merkel 1991; Shimada and Wagner 2007) has termed "modular organization" that crosscut a variety of Sicán productive activities ranging from corporate architectural construction to craft production.

At Cerro Huaringa and nearby Cerro Sajino, copper-arsenic smelting was carried out at a series of contiguously built workshops with similar dimensions, organization and equipment, each equipped with a row of smelting furnaces, one to three 
batán-chungo sets, a charcoal storage pit, and at least one large storage urn that probably kept water for workers (Epstein 1993; Epstein and Shimada 1984; Figure 18). This general technological homogeneity and organizational redundancy did not eliminate variation among workshops. For example, the number of furnaces (and presumably workers) in each workshop varied from 3 to 5 . During the Middle and Late Sicán periods, tuyeres were distinctly decorated and made with pastes prepared with ground glassy slag as a temper, suggesting the self-sufficient character of these workshops (emphasis added; Shimada and Merkel 1991). In general, prior to the establishment of the administrative control of production by the intrusive Chimú state starting from the end of the 14th century (Epstein 1993; Epstein and Shimada 1984), there is little evidence of standardization or streamlining of production (Bezúr 2003; Shimada and Merkel 1991). During the earlier Sicán periods, each workshop had a good deal of autonomy in their daily productive activities resulting in an appreciable amount of product variability among workshops (emphasis added).
Essentially the same picture of organizational and productive redundancy and autonomy emerged at the Middle Sicán ceramic and metalworking (copper-arsenic alloys and gold alloys) site of Huaca Sialupe (Figure 2). Potters of inferred Moche ethnicity independently produced basically the same array of mold-made ceramics of similar quality and finish in contiguous but discrete rooms (Klaus 2003; Shimada and Wagner 2007; Taylor 2002). They produced vessels of Sicán and persistent Moche styles concurrently at the workshop. The use of molds assured that the same forms and images were produced efficiently at the level of individual potter or group of potters, but neither streamlined production nor standardized products at the site level (Shimada and Wagner 2007); in other words, the specific châine opératoire and the number of molds used to produce them differed just as did their decoration in minor details. Formed ceramic vessels were then fired in small batches using small kilns that varied in size and shape but were placed close to each other in a large open, well-ventilated area. Highly efficient, natural draft-based metalworking

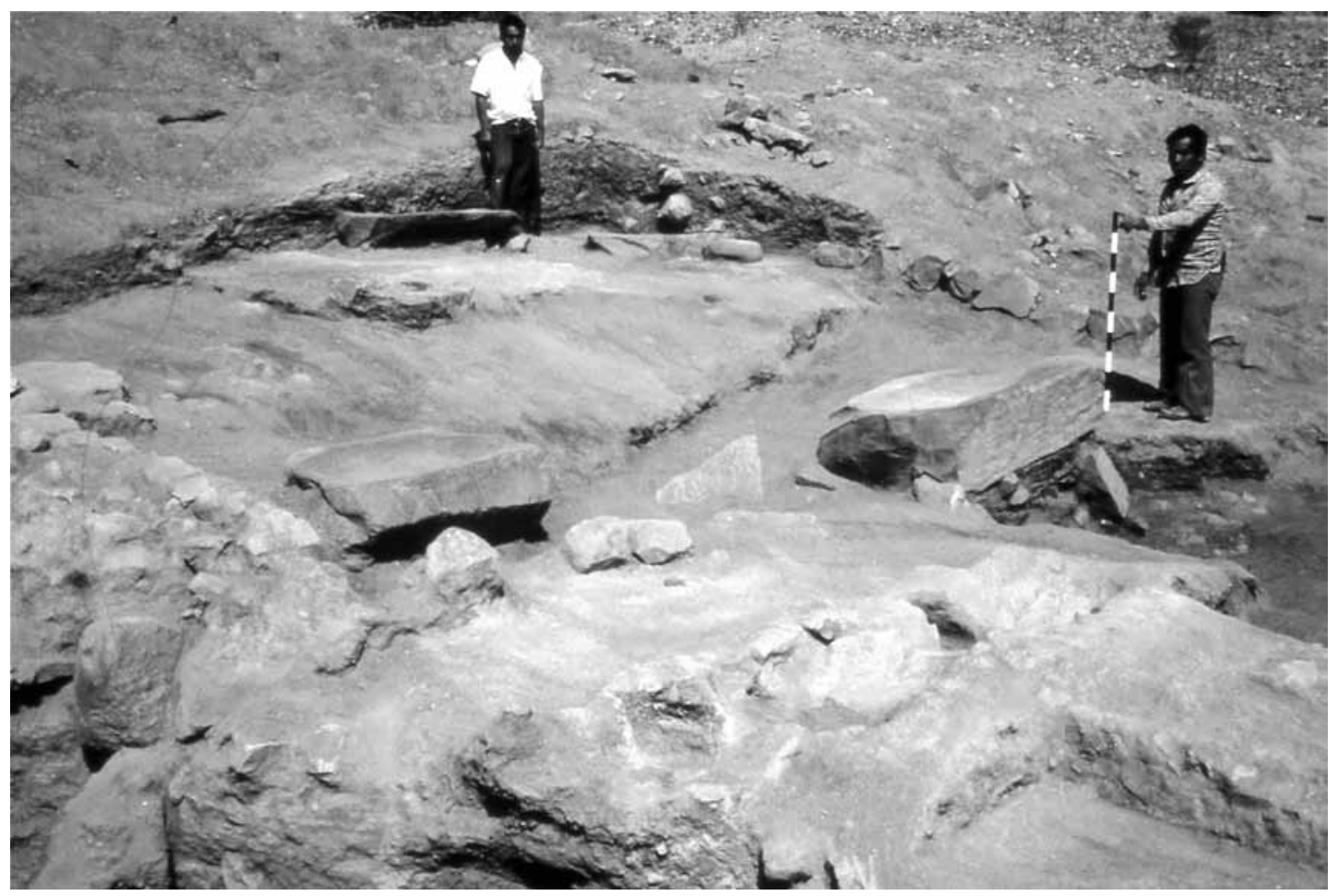

Figure 18. A Late Sicán smelting workshop at Cerro Huaringa Sector III. Note a row of smelting furnaces in foreground and three well-worn batanes. Photo by Izumi Shimada.

Un taller de fundición del período Sicán Tardío en el Sector III, Cerro Huaringa. Nótese una hilera de hornos de fundición en primer plano y tres batanes bastante desgastados. Foto de Izumi Shimada. 


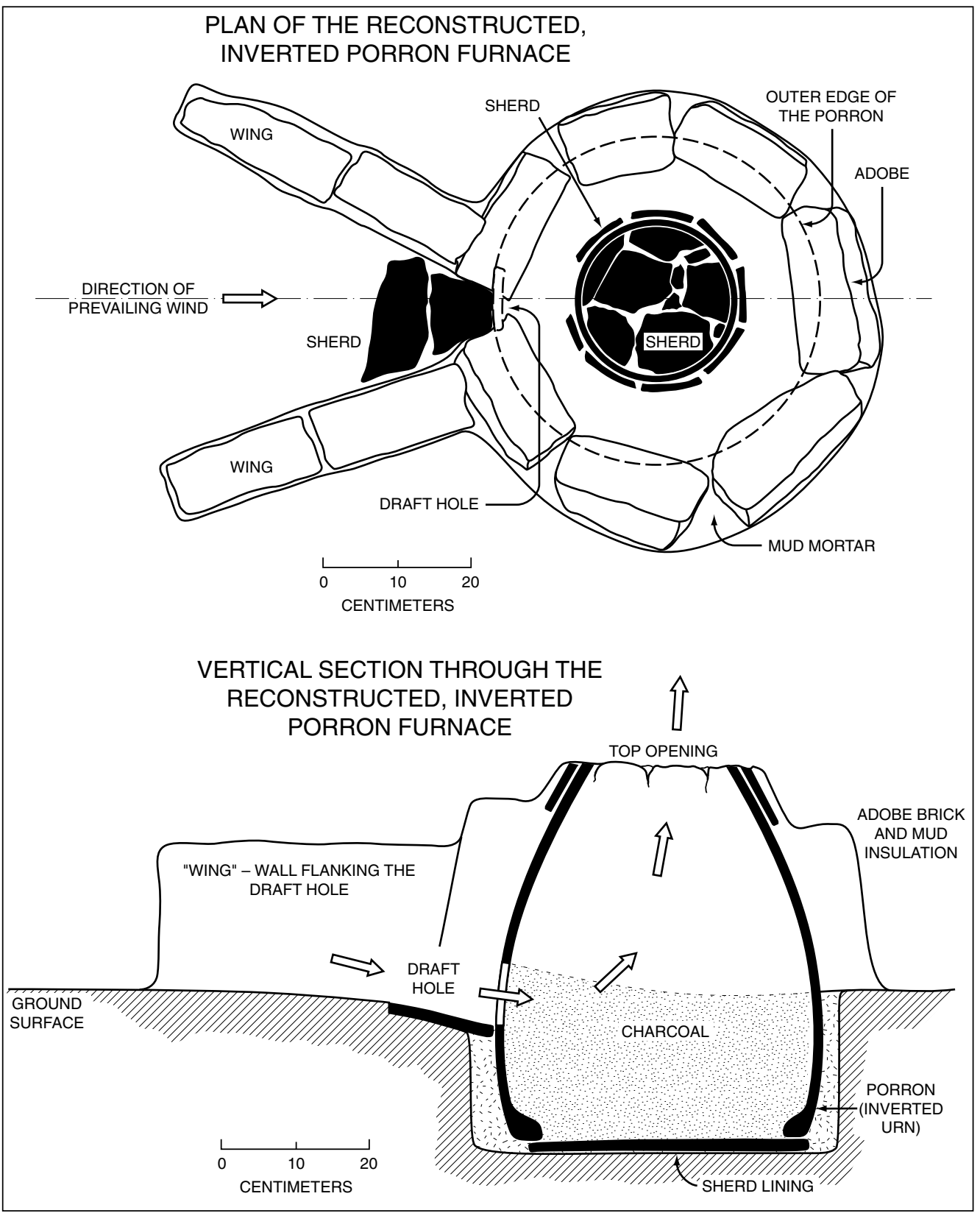

Figure 19. Construction of a Middle Sicán metalworking furnace built with a well-insulated, inverted ceramic urn excavated at Huaca Sialupe. Drawing by Izumi Shimada.

Diferentes vistas de un horno de metalistería Sicán Medio construido con una botija grande invertida y bien aislado encontrado en el taller de Huaca Sialupe. Dibujo de Izumi Shimada.

furnaces (Figure 19) that varied in size and construction details were similarly organized in a distinct area of this site (Shimada et al. 2007; Shimada and Wagner 2007; see Figure 17).

In essence, the same redundant, modular approach was employed for both ceramic production and metalworking throughout their respective châine opératoire (Figure 20). Only in a general sense (emphasis added) can we speak of standardized products.

These examples show the clear preference for relatively small-scale production units that, while 


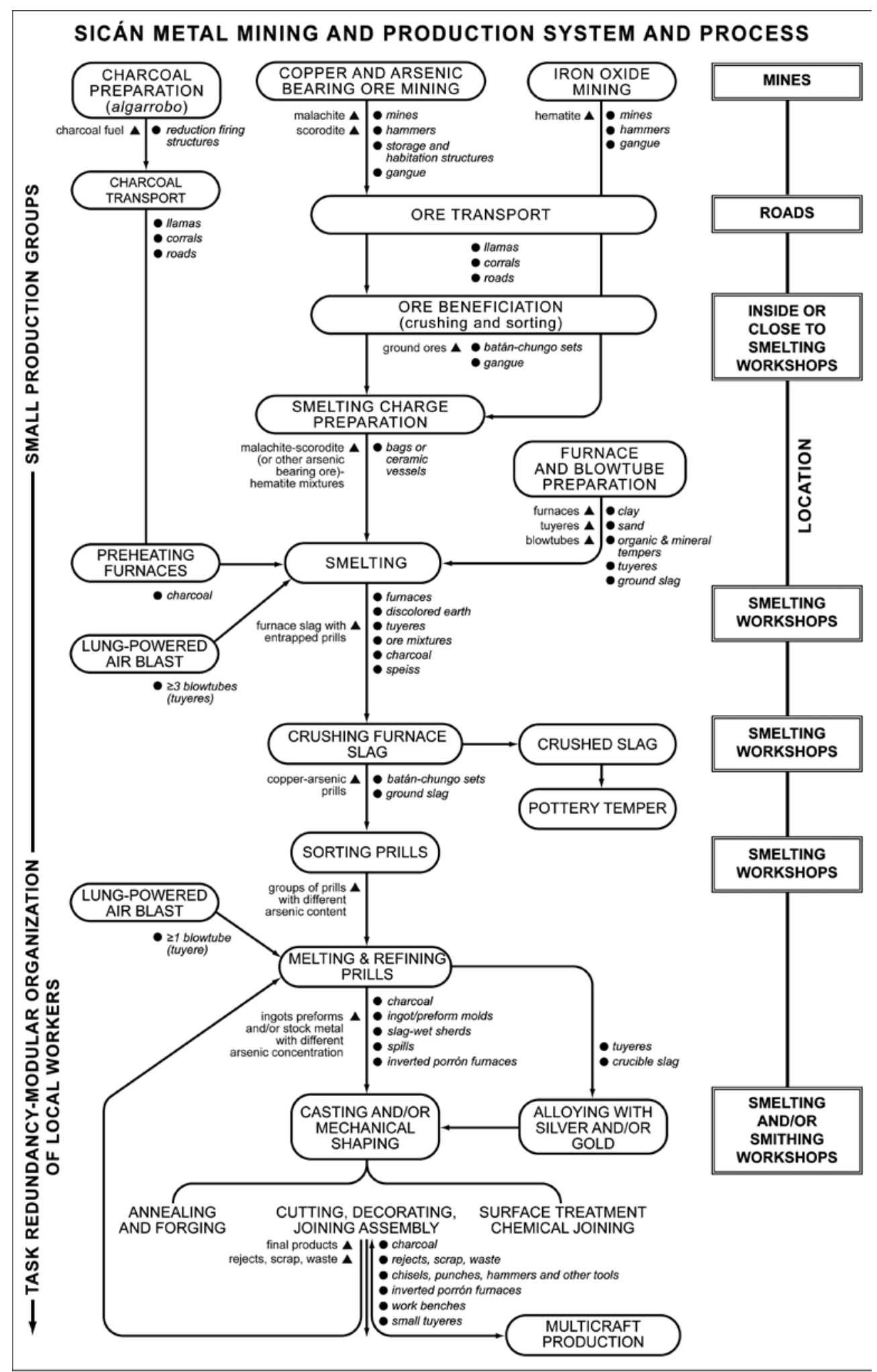

Figure 20. Châine opératoire of the Sicán metallurgical process. Drawing by Izumi Shimada and Steve Mueller. Châine opératoire (secuencia de operación) del proceso metalúrgico Sicán. Dibujo de Izumi Shimada y Steve Mueller. 
sharing basic technology and achieving equivalent or similar outputs, enjoyed a good degree of technical, artistic and perhaps even political, autonomy. This modular approach to productive activities had characterized the preceding Late Moche society as well (Shimada 2001).

The existence of multiple smelting centers each in close proximity to at least one mine clearly points to the considerable economic and political importance of copper-arsenic alloy production. At the same time, we do not see the overriding concern for productive efficiency at either individual sites or the regional level that one might expect during the Sicán periods. We argue that this situation reflects the multi-ethnic composition of Sicán society in which a local ethnic Moche population constituted the primary labor force administered by the ethnic Sicán elites. This multi-ethnicity and attendant social inequality have been documented by multiple independent lines of evidence - iconographic representations, genetic variation and patterns elucidated by biodistance and mitochondrial DNA analyses, paleo-mobility and dietary data from stable isotope analyses (strontium, oxygen, carbon and nitrogen), and differences in mortuary practices and health status, among others (Klaus et al. 2011; Shimada 2009; Shimada et al. 2004). For the Sicán polity, preserving the existing ethnic/kinship-based social fabric and groups, each with its own functioning political and administrative setups would have minimized both potential social and political conflicts among the subject populations and investment of administrative personnel and resources, while gaining a desired quantity of workable/acceptable (as opposed to highly standardized and refined) products. Ethnic Moche workers would have retained a sense of social autonomy and identity, at the same time, effectively preserving the technical knowledge, skills and style that they inherited from their own renowned predecessors. One wonders if the inferred organization and accompanying mindset or psychology contributed to the strong temporal continuity and conservatism of Sicán mining and metallurgy.

\section{Conclusion}

The subject of pre-Hispanic metal mining has remained under-studied and under-appreciated. To advance and attract a wider range of researchers to the subject, it is critical that mining and metallurgy be investigated as an integrated process and system and that its behavioral, social and ideological significance be explored in depth. The holistic approach we advocate is an ambitious undertaking that entails a regional, multi-site perspective and long-term, interdisciplinary collaboration in and out of the field focusing on both production and use contexts. We hope we were able to illustrate in this paper that such investment of time and effort is, indeed, worthwhile as it generates valuable insights and reveals varied and important connections among different facets and phases of the integrated process of mining and metallurgy.

Acknowledgements: This paper presented salient findings and insights gained on Sicán archaeometallurgy over the course of more than three decades of investigation by the Sicán Archaeological Project under the direction of I. Shimada. For their generous support of our research, we thank the Committee for Research and Exploration of the National Geographic Society, the National Science Foundation, the Tokyo Broadcasting System, the Wenner-Gren Foundation for Anthropological Research, and the Heinz Family Foundation. Many Project members contributed to our archaeometallurgical research; in particular, we are grateful to Aniko Bézur, Stephen M. Epstein, John F. Merkel, Juan Carlos Santoyo, and José Luis Suarez. Melody J. Shimada provided valuable editorial critique on an earlier and this version of our paper. Lastly, we also thank the members of the organizing committee of the Primera Reunión Internacional sobre Minería Prehispánica en América for inviting us to present an earlier draft this paper. 


\section{References Cited}

Bergsøe, P. 1937. The Metallurgy and Technology of Gold and Platinum Among the Pre-Columbian Indians. Ingeniørvidenskabelige Skrifter, Nr. A 44. Danmarks Naturvidenskabelige Samfund i Kommission Hos G.E.C. Gad. København.

- - - 1938. The Gilding Process and the Metallurgy of Copper and Lead Among the Pre-Columbian Indians. Translated from Danish by C. Reynolds. Ingeniørvidenskabelige Skrifter, Nr. A 46. Danmarks Naturvidenskabelige Samfund i Kommission Hos G.E.C. Gad. København.

Bernier, H. 2010. Craft specialists at Moche: Organization, affiliations, and identities. Latin American Antiquity 21:22-43.

Bezúr, A. 2003. Variability in Sicán Copper Alloy Artifacts. Doctoral Dissertation, Department of Materials Science and Engineering, University of Arizona, Tucson.

Bird, J. 1979. The "Copper Man": A prehistoric miner and his tools from northern Chile. In Pre-Columbian Metallurgy of South America, edited by E.P. Benson, pp. 105-132. Dumbarton Oaks, Washington, D.C.

Boman, É. 1908. Antiquités de la Région Andine de la République Argentine et du Désert d'Atacama. Mission scientifique G. de Créqui Montfort et E. Sénéchal de la Grange, Paris.

Caley, E. 1973. Chemical composition of ancient copper objects of South America. In The Application of Science in Examination of Works of Art, edited by W. Young, pp. 53-61. Museum of Fine Art, Boston.

Caley, E., and D. Easby, Jr. 1959. The smelting of sulfide ores of copper in preconquest Peru. American Antiquity 25:59-65.

Caley, E., and L. Shank 1971. Composition of ancient Peruvian copper. Ohio Journal of Science 71:181-187.

Carter, B.P. 2008. Technology, Society and Change: Shell Artifact Production among the Manteño (A.D. 800-1532) of Coastal Ecuador. Doctoral dissertation. Department of Anthropology, Washington University, St. Louis, MO.

Castillo B., L. 2001. The last of the Mochicas: A view from the Jequetepeque valley. In Moche Art and Archaeology in Ancient Peru, edited by Joanne Pillsbury, pp. 307-332. National Gallery of Art, Studies in History of Art 63, Washington D.C.

Chapdelaine, C. 2010. Moche and Wari during the Middle Horizon on the north coast of Peru. In Beyond Wari Walls: Exploring the Nature of Middle Horizon Peru Away from Wari Centers, edited by Justin Jennings, pp. 213-232. University of New Mexico Press, Albuquerque.

Cleland, K., and I. Shimada 1992. Sicán bottles: Marking time in the Peruvian bronze age. Andean Past 3:193-235.

Costin, C.L. 2001. Craft production systems. In Archaeology at the Millennium: A Sourcebook, edited by Gary M. Feinman and T. Douglas Price, pp. 273-327. Kluwer Academic/Plenum Publishers, New York.

Costin, C.L., and R. Wright (eds.) 1998. Social Relations of Technology. American Anthropological Association, Washington D.C.
Craddock, P.T. 1992. A short history of firesetting. Endeavour 16(2):145-150.

- - - 1995. Early Metal Mining and Production. Smithsonian Institution Press, Washington D.C.

Craig, A. K., and I. Shimada 1986. El Niño flood deposits of Batán Grande, northern Peru. Geoarchaeology: An International Journal 1:29-38.

Cushing, F.H. 1894. Primitive copper working: An experimental study. American Anthropologist 7:93-117.

Dobres, M.A., and C. Hoffman 1994. Social agency and the dynamics of prehistoric technology. Journal of Archaeological Method and Theory 3:211-258.

Donnan, C.B., D.A. Scott, and T. Bracken 2008. Moche forms for shaping sheet metal. In The Art, the Arts and the Archaeology of the Moche: An Ancient Andean Society of the Peruvian North Coast, edited by S. Bourget and K.L. Jones, pp. 113-128. University of Texas Press, Austin.

Epstein, S. M. 1993. Cultural Choice and Technological Consequences: Constraints of Innovation in the Late Prehistoric Copper Smelting Industry of Cerro Huaringa, Peru. Doctoral Dissertation, Department of Anthropology, University of Pennsylvania, Philadelphia.

Epstein, S.M., and I. Shimada 1984. Metalurgia de Sicán: Una reconstrucción de la producción de la aleación de cobre en el Cerro de los Cementerios, Perú. Beiträge zur Allgemeinen und Vergleichenden Archäologie 5:379-430.

Fuller, D.R. 2004. The production of copper in 6th century Chile's Chuquicamata mine. Journal of Metals 56(11):62-66.

Glowacki, M. 2005. Food of the gods or mere mortals? Hallucinogenic Spondylus and its interpretive implications for early Andean society. Antiquity 79:257-268.

Goldstein, D.J. 2007. Forests and Fires: Dry Tropical Forest Management, Metallurgy, and Ceramic Production in Lambayeque, Peru, during the Middle Sicán (950-1050 C.E.). Doctoral Dissertation, Department of Anthropology Southern Illinois University, Carbondale.

Goldstein, D.J., and I. Shimada 2007. Middle Sicán multi-craft production: Resource management and labor organization. In Craft Production in Complex Societies: Multi-Crafting, Sequential Production, and Producers, edited by I. Shimada, pp. 44-67. University of Utah, Salt Lake City.

Gosden, C., and Y. Marshall 1999. The cultural biography of objects. World Archaeology 31:169-178.

Hayashida, F.M. 2009. The Proyecto Ynalche: Late prehispanic political economy on the Pampa de Chaparrí. Paper presented at the 73rd annual meeting of the Society for American Archaeology, Atlanta, GA.

Heyerdahl, T., D.H. Sandweiss, and A. Narváez 1995. Pyramids of Túcume: The Quest for Peru's Forgotten City. Thames and Hudson, London.

Jennings, J. 2008. Catastrophe, revitalization, and religious change on the prehispanic North Coast of Peru. Cambridge Archaeological Journal 18:177-194. 
Jones, A. 2002. Archaeological Theory and Scientific Practice. Cambridge University Press, Cambridge.

Jones, J. 1979. Mochica works of art in metal: A review. In PreColumbian Metallurgy of South America, edited by E. P. Benson, pp. 53-104. Dumbarton Oaks, Washington, D.C.

Klaus, H.D. 2003. Life and Death at Huaca Sialupe: The Mortuary Archaeology of a Middle Sicán Community, North Coast of Peru. Masters thesis, Department of Anthropology, Southern Illinois University, Carbondale.

Klaus, H.D., I. Shimada, K. Shinoda, and S. Muno 2011. Middle Sicán mortuary archaeology, skeletal biology, and genetic structure: Human biocultural variation in an ancient South American complex society. In Osteology of Hierarchy, edited by M. Cohen and G. Krane-Cramer. University of Florida Press, Gainesville, in press.

Kosok, P. 1959. El valle de Lambayeque. Actas y Trabajos del II Congreso Nacional de Historia del Perú: Epoca PreHispánica 1:69-76.

- - - 1965. Life, Land and Water in Ancient Peru. Long Island University, New York.

Kroeber, A.L. 1954. Quantitative analyses of ancient Peruvian metal. American Antiquity 20:160-162.

Lechtman, H.N. 1973. The gilding of metals in precolumbian Peru. In The Application of Science in Examination of Works of Art, edited by W.J. Young, pp. 38-52. Museum of Fine Art, Boston.

- - - 1976. A metallurgical site survey in the Peruvian Andes. Journal of Field Archaeology 3:1-42.

- - - 1977. Style in technology: Some early thoughts. In Material Culture: Styles, Organization, and Dynamics of Technology, edited by H.N. Lechtman and R.S. Merrill, pp. 3-20. West Publishing, St. Paul.

- - - 1979. Issues in Andean metallurgy. In Pre-Columbian Metallurgy of South America, edited by E.P. Benson, pp. 1-40. Dumbarton Oaks, Washington D.C.

- - - 1981. Copper-arsenic bronzes from the north coast of Peru. Annals of the New York Academy of Sciences 376:77-122.

- - - 1984. Andean value system and the development of prehistoric metallurgy. Technology and Culture 25:1-36.

- - - 1988. Traditions and styles in Central Andean metalworking. In The Beginning of the Use of Metals and Alloys, edited by R. Maddin, pp. 344-378. MIT Press, Cambridge.

- - - 1991. The production of copper-arsenic alloys in the Central Andes: Highland ores and coastal smelter? Journal of Field Archaeology 18:43-76.

- - - 1996. Arsenic bronze: Dirty copper or chosen alloy? A view from the Americas. Journal of Field Archaeology 23:477-514.

Lechtman, H.N., A. Erlij, and E.J. Barry, Jr. 1982. New perspectives on Moche metallurgy: Techniques of gilding copper at Loma Negra, northern Peru. American Antiquity 47:3-30.

Lechtman, H.N., and S. Klein 1999. The production of copperarsenic alloys (arsenic bronze) by cosmelting: Modern experiment, ancient practice. Journal of Archaeological Science 26:497-526.
Lemonnier, P. 1993. Introduction. In Technological Choices: Transformation in Material Cultures since the Neolithic, edited by Pierre Lemonnier, pp. 1-35. Routledge, London and New York.

Mackey, C. 2000. Los dioses que perdieron los colmillos. In Los Dioses del Antiguo Perú, edited by Krzysztof Makowski, pp. 110-157. Colección Arte y Tesoros del Perú, Banco del Crédito del Perú, Lima.

Mathewson, C.H. 1915. A metallographic description of some ancient Peruvian bronzes from Machu Picchu. American Journal of Science 40:526-616.

Mead, C.W. 1915. Prehistoric bronze in South America. Anthropological Papers of the American Museum of Natural History 12 (2):16-52.

- - - 1921. Prehistoric mining in western South America. Natural History 21(5):453-456.

Menzel, D. 1977. The Archaeology of Ancient Peru and the Work of Max Uhle. R.H. Lowie Museum of Anthropology, Berkeley.

Merkel, J.F., I. Shimada, C.P. Swann, and R. Doonan 1994. Investigation of prehistoric copper production at Batán Grande, Peru: Interpretation of the analytical data for ore samples. In Archaeometry of Pre-Columbian Sites and Artifacts, edited by D. A. Scott and P. Meyers, pp. 199-227. The Getty Conservation Institute, Marina del Rey.

Nordenskiöld, E. 1921. The Copper and Bronze ages in South America. Comparative Ethnographical Studies (Vol. 4), Erlanders Boktryckeri Aktiebolag, Göteborg.

Oehm, V.P. 1984. Investigaciones sobre Minería y Metalurgia en el Perú Prehispánico: Una Visión Crítica Actualizada. Bonner Amerikanistische Studien No.12, Bonn.

Patterson, C.C. 1971. Native copper, silver, and gold accessible to early metallurgists. American Antiquity 36:286-321.

Paulsen, A.C. 1974. The thorny oyster and the voice of god: Spondylus and Strombus in Andean prehistory. American Antiquity 39:597-607.

Pedersen, A. 1976. El ajuar funerario de la tumba de la Huaca Menor de Batán Grande, Lambayeque, Perú. Actas del 41 Congreso Internacional de Americanistas, pp. 60-73. Instituto Nacional de Antropología e Historia, Mexico City.

Petersen, G. 1970. Minería y Metalurgia en el Antiguo Perú. Arqueológicas 12, Museo Nacional de Antropología y Arqueología, Lima.

Raimondi, A. 1878. Minerales del Perú o Catálogo razonado de una Colección que representa los principales Tipos de Minerales de la República con Muestras de Huano y Restos de Aves que lo han producido. Imprenta del Estado, Lima.

- - - 2004 [1887]. Minas de oro del Perú. In Colección Estudios Geológicos y Mineros para la obra "El Perú", Volume I, compiled by L.F. Villacorta, pp. 93-159. Compañía de Minas Buenaventura, Asociación Educacional Antonio Raimondi, Fondo Editorial de la Universidad Nacional Mayor de San Marcos, Lima.

Ramírez, S.E. 1994. Ethnohistorical dimensions of mining and metallurgy in sixteenth-century northern Peru. In In Quest of Mineral Wealth: Aboriginal and Colonial Mining and Metallurgy 
in Spanish America, edited by A.K. Craig and R. West, pp. 93108. Louisiana State University, Baton Rouge.

Rondón, J. 1965/66. Morfología de la cerámica en relación a las normas prestadas del metal. Revista del Museo Nacional 34:82-84.

Rostoker, W. and J.R. Dvorak 1991. Some experiments with co-smelting to copper alloys. Archeomaterials 5:5-20.

Salomon, F., and J. Urioste (eds.) 1991. The Huarochirí Manuscript: A Testament of Ancient and Colonial Andean Religion. University of Texas Press, Austin.

Schaedel, R.P. 1972. The city and the origin of the state in America. Actas y Memorias del 39 Congreso Internacional de Americanistas, pp. 15-33. Instituto de Estudios Peruanos, Lima.

- - - 1993. Congruence of horizon with polity: Huari and the Middle Horizon. In Latin American Horizons, edited by Don S. Rice, pp. 225-262. Dumbarton Oaks, Washington, D.C.

Schiffer, M. B., and J.M. Skibo 1987. Theory and experiment in the study of technological change. Current Anthropology 28:595-622.

Segura, R.A., and I. Shimada 2012. Examining Middle SicánCentral Coast interaction, ca. AD 1000. In Cultura Sicán: Esplendor Preinca de la Costa Norte, edited by I. Shimada. Editorial del Congreso de Perú, Lima. In press.

Sellet, F. 1993.Chaîne opératoire: The concept and its application. Lithic Technology 18:106-112.

Shimada, I. 1985a. Perception, procurement and management of resources: Archaeological perspective. In Andean Ecology and Civilization, edited by S. Masuda, I. Shimada, and C. Morris, pp. 357-399. University of Tokyo Press, Tokyo.

- - - 1985b. La cultura Sicán: Caracterización arqueológica. In Presencia Histórica de Lambayeque, edited by E. Mendoza S., pp. 76-133. Editorial e Imprenta DESA S.A., Lima.

- - - 1990. Cultural continuities and discontinuities on the northern north coast, Middle-Late Horizons. In The Northern Dynasties: Kingship and Statecraft in Chimor, edited by M.E. Moseley and A. Cordy-Collins, pp. 297-392. Dumbarton Oaks, Washington, D.C.

- - - 1994a. Prehispanic metallurgy and mining in the Andes: Recent advances and future tasks. In In Quest of Mineral Wealth: Aboriginal and Colonial Mining and Metallurgy in Spanish America, edited by Alan K. Craig and Robert West, pp. 37-73. Louisiana State University, Baton Rouge.

- - - 1994b. The role of metals in Middle Sicán society. In The Illustrated Encyclopedia of Humankind, Vol. 4: New World and Pacific Civilizations, edited by Goran Burenhult, pp. 94-95. Weldon Owen Pty Limited, Sydney.

- - - 1995. Cultura Sicán: Dios, Riqueza y Poder en la Costa Norte del Perú. Edu-Banco Continental, Lima.

- - - 1999. The evolution of Andean diversity: Regional formations, ca. 500 B.C. - A.D. 600. In Cambridge History of Native Peoples of the Americas, edited by F. Salomon and S. Schwartz, pp. 350-517. Cambridge University Press, Cambridge.

- - - 2000. Late prehispanic coastal states. In The Inca World: The Development of Pre-Columbian Peru, A.D. 1000-1534, edited by L. Minelli, pp. 49-110. University of Oklahoma Press, Norman.
- - - 2001. Late Moche urban craft production: A first approximation. In Moche Art and Archaeology in Ancient Peru, edited by J. Pillsbury, pp. 177-205. National Gallery of Art, Studies in History of Art 63. Washington, D.C.

- - - 2005. Experimental archaeology. In Handbook of Archaeological Methods, Vol. I, edited by H. Maschner and Ch. Chippindale, pp. 603-642. Alta Mira Press, Lanham, MD.

- - - 2009. Who were the Sicán? Their development, characteristics, and legacies. In The Golden Capital of Sicán, edited by I. Shimada, K. Shinoda, and M. Ono, pp. 25-61. Tokyo Broadcasting System, Tokyo.

Shimada, I., V. Chang, C.G. Elera, H. Neff, M. Glascock, U. Wagner, and R. Gebhard 1994. Los hornos y la producción de cerámica formativa en Batán Grande, costa norte del Perú. In $L a$ Tecnología y la Organización de Producción de las Cerámicas en los Andes Prehispánicos, edited by I. Shimada, pp. 67-119. Fondo Editorial, Pontificia Universidad Católica del Perú, Lima.

Shimada, I., S.M. Epstein, and A.K. Craig 1982. Batán Grande: A prehistoric metallurgical center in Peru. Science 216:952-959.

Shimada, I., D.J. Goldstein, W Häusler, J. Sosa, and U. Wagner 2003. Early pottery making in northern coastal Peru: Part II: Field firing experiments. In Mössbauer Spectroscopy in Archaeology, Volume II, edited by U. Wagner, pp. 91-105. Kluwer Publishing, New York.

Shimada, I., D.J. Goldstein, U Wagner, and A. Bezúr 2007. Pre-Hispanic Sicán furnaces and metalworking: Toward a holistic understanding. In Metalurgia en la América Antigua: Teoría, Arqueología, Simbología y Tecnología de los Metales Prehispánicos, edited by R. Lleras Pérez, pp. 337-361. Travaux de l'Institut Français d'Études Andines No. 253, Fundación de Investigaciones Arqueológicas Nacionales, Banco de la República, Bogotá, and Instituto Francés de Estudios Andinos, Lima.

Shimada, I., A. Gordus, and J.A. Griffin 2000. Technology, iconography, and significance of metals: A multi-dimensional analysis of Middle Sicán objects. In Pre-Columbian Gold: Technology, Iconography, and Style, edited by C. McEwan, pp. 28-61. The British Museum Press, London.

Shimada, I., A. Gordus, J.A. Griffin, and J.F. Merkel 1999. Sicán alloying, working and use of precious metals: An interdisciplinary perspective. In Metal in Antiquity, edited by S. M. M. Young, A. M. Pollard, P. Budd, and R. A. Ixer. pp. 301-309. BAR International Series 792, Archaeopress, Oxford.

Shimada, I., and J.A. Griffin 1994. Precious metal objects of the Middle Sicán. Scientific American 270(4):60-67.

Shimada, I., and J.F. Merkel 1987. Sicán metallurgy: Holistic understanding and the role of archaeometry. Paper presented at the 52nd Annual Meeting of the Society for American Archaeology, Toronto.

- - - 1991. Copper alloy metallurgy in ancient Peru. Scientific American 265(1):80-86.

Shimada, I., C. Schaaf, L.G. Thompson, and E. Mosley-Thompson 1991. Implicaciones culturales de una gran sequía del siglo VI d.C. en los Andes peruanos. Boletín de Lima XIII 77:33-56.

Shimada, I., K. Shinoda, J. Farnum, R.S. Corruccini and H. Watanabe 2004. An integrated analysis of pre-Hispanic mortuary 
practices: A Middle Sicán case study. Current Anthropology 45:369-402.

Shimada, I., and U. Wagner 2001. Peruvian black pottery production and metalworking: A Middle Sicán craft workshop at Huaca Sialupe. Materials Research Society Bulletin 26:25-30.

- - - 2007. Craft production on the pre-Hispanic north coast of Peru: A holistic approach and its results. In Archaeology as Anthropology: Theoretical and Methodological Approaches, edited by J. Skibo, M. Grave and M. Stark, pp. 163-197. University of Arizona Press, Tucson.

Sillar, B., and M. Tite (eds.) 2000.Technological choices in ceramic production. Archaeometry 42(1):1-254.

Skibo, J. 1992. Pottery Function: A Use-Alteration Perspective. Plenum Press, New York.

Taylor, S.R. 2002. Artisan Autonomy in the Middle Sicán State: Variability in Mold-Made Ceramic Production. Masters thesis,
Department of Anthropology, Southern Illinois University, Carbondale.

Topic, J. 1990. Craft production in the kingdom of Chimor. In The Northern Dynasties: Kingship and Statecraft in Chimor, edited by M. E. Moseley and A. Cordy-Collins, pp. 145-176. Dumbarton Oaks, Washington, D.C.

Vaughn, K.J., J.W. Eerkens, M. Linares Grados, and M.J. Edwards 2007. Hematite mining in the ancient Americas: Mina Primavera, a 2,000 year old Peruvian mine. JOM 59 (December): 21-25

Villacorta, L.F. 2004. Antonio Raimondi, contexto histórico de su labor geológica y minera. In Colección Estudios Geológicos y Mineros para la Obra "El Perú", Volume I, compiled by L.F. Villacorta, pp. 19-66. Compañía de Minas Buenaventura, Asociación Educacional Antonio Raimondi, Fondo Editorial de la Universidad Nacional Mayor de San Marcos, Lima. 
